\title{
Technetium Oxidation in Slag-based Sodium Salt Waste Forms Exposed to Water and Moist Hanford Soil
}

C.A. Langton

August 2014

SRNL-STI-2014-00399, Revision 0 
SRNL-STI-2014-00399

Revision 0

\section{DISCLAIMER}

This work was prepared under an agreement with and funded by the U.S. Government. Neither the U.S. Government or its employees, nor any of its contractors, subcontractors or their employees, makes any express or implied:

1. warranty or assumes any legal liability for the accuracy, completeness, or for the use or results of such use of any information, product, or process disclosed; or

2. representation that such use or results of such use would not infringe privately owned rights; or

3. endorsement or recommendation of any specifically identified commercial product, process, or service.

Any views and opinions of authors expressed in this work do not necessarily state or reflect those of the United States Government, or its contractors, or subcontractors.

Printed in the United States of America

Prepared for

U.S. Department of Energy 
SRNL-STI-2014-00399

Revision 0

Keywords: Tc Oxidation

Retention: Permanent

\section{Tc OXIDATION IN SLAG-BASED SODIUM SALT WASTE FORMS EXPOSED TO WATER AND MOIST HANFORD SOIL}

C. A. Langton

August 2014

Prepared for the U.S. Department of Energy under contract number DE-AC09-08SR22470.

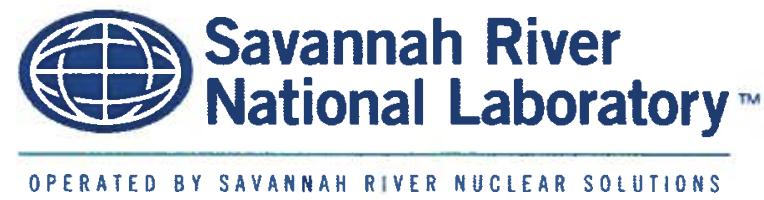




\section{Executive Summary}

The attached report documents a scoping study intended to evaluate leaching results of depth-discrete sub-samples of a sodium salt cementitious waste forms which were exposed to water and to unsaturated Hanford sediment in a 1-D experimental configuration.

Based on nitrate (assumed to $100 \%$ soluble during curing and exposure) leaching results for the depthdiscrete subsamples, depletion regions were identified which extended 9.5 and $3 \mathrm{~mm}$ into samples Tc2-9 (exposed to Hanford sediment) and Tc2-10 (DI water), respectively. Lower mass fractions of nitrate were leached from the depth-discrete samples taken near the exposed surface. One explanation is that a significant portion of the nitrate had already migrated into the soil or the water.

Leachability of technetium was interpreted to be an indicator of the technetium oxidation state. Leachable / soluble Tc was assumed to be in the oxidized form, Tc(VII), and non-leachable Tc was assumed to be in the reduced form, Tc(IV). Leachable and non-leachable Tc (mixed oxidation states) were detected in all of the depth-discrete subsamples collected over the entire length of the $9 \mathrm{~cm}$ sample exposed to water and to moist soil. Details of the experiments and results are provided in the attached report. More soluble Tc was measured in the sample exposed to moist soil than was measured in the sample submerged in deionized water. One explanation is that moist Hanford sediment did not completely block the surface pores with respect to gas transport across the soil-waste form boundary, whereas, water formed an effective barrier to oxygen gas ingress.

Leaching waste forms containing redox sensitive contaminants, e.g. Tc-99, in water may not be conservative if the intended disposal site is in unsaturated soil and /or if extended exposure air $\left(\mathrm{O}_{2}\right)$ in a disposal container or engineered structure is anticipated. Leaching in unsaturated soil is more conservative and representative of vadose zone disposal conditions especially in arid environment environments. 


\section{TABLE OF CONTENTS}

EXECUTIVE SUMMARY.

ATTACHMENT 1. Technetium Oxidation in Slag-based Sodium Salt Waste Forms Exposed to Water and Moist Hanford Soil.......................................A-1 


\section{ATTACHMENT 1 \\ CEMENT BARRIERS PARTNERSHIP}

Technetium Oxidation in Slag-based Sodium Salt Waste Forms

Exposed to Water and Moist Hanford Soil 


\section{TECHNETIUM OXIDATION IN SLAG-BASED SODIUM SALT WASTE FORMS EXPOSED TO WATER AND MOIST HANFORD SOIL}

\section{Cementitious Barriers Partnership}

August 2014 


\title{
ACKNOWLEDGEMENTS
}

This report was prepared for the United States Department of Energy under Interagency Agreement No. DE-AI09-09SR22667 and is an account of work performed under that contract. This report was also prepared with the financial support by the U. S. Department of Energy, under Cooperative Agreement Number DE-FC01-06EW07053 entitled 'The Consortium for Risk Evaluation with Stakeholder Participation III' awarded to Vanderbilt University. Reference herein to any specific commercial product, process, or service by trademark, name, manufacturer, or otherwise does not necessarily constitute or imply endorsement, recommendation, or favoring of same by Savannah River Nuclear Solutions, Vanderbilt University or by the United States Government or any agency thereof. The views and opinions of the authors expressed herein do not necessarily state or reflect those of the United States Government or any agency thereof. This report is part of a larger multi-investigator project supported by the U. S. Department of Energy entitled the Cementitious Barriers Partnership. The opinions, findings, conclusions, or recommendations expressed herein are those of the authors and do not necessarily represent the views of the U.S. Department of Energy. This work was also partially supported by the National Institute of Standards and Technology Sustainable, High Performance Infrastructure Materials program.

\section{DISCLAIMER}

This work was prepared under an agreement with and funded by the U. S. Government. Neither the U.S. Government or its employees, nor any of its contractors, subcontractors or their employees, makes any express or implied: 1. warranty or assumes any legal liability for the accuracy, completeness, or for the use or results of such use of any information, product, or process disclosed; or 2. representation that such use or results of such use would not infringe privately owned rights; or 3 . endorsement or recommendation of any specifically identified commercial product, process, or service. Any views and opinions of authors expressed in this work do not necessarily state or reflect those of the United States Government, or its contractors, or subcontractors.

\author{
Printed in the United States of America \\ United States Department of Energy \\ Office of Environmental Management \\ Washington, DC
}

\author{
This document is available on the U.S. DOE Information Bridge and on the \\ CBP website: http://cementbarriers.org/ \\ An electronic copy of this document is also available through links on the following
}




\section{SUMMARY}

Cementitious materials are used to solidify and stabilize aqueous based radioactive waste containing sodium salts. The types and proportions of cementitious ingredients used to treat aqueous radioactive waste streams containing sodium salts depend on the performance objectives for the waste forms and the compositions of the waste streams.

Several U.S. DOE sites use or plan to use waste forms and/or concrete containment structures for radioactive waste disposal that are designed to have a chemically reducing environment to immobilize selected contaminants such as $\mathrm{Tc}(\mathrm{VII}) \mathrm{O}_{4}{ }^{-}$and $\mathrm{Cr}(\mathrm{VI}) \mathrm{O}_{4}{ }^{2-}$. These waste forms and containment structures are typically deployed in near surface unsaturated oxidizing environments. Consequently, the effect of exposure to air (oxygen) and water containing dissolved oxygen during production, during the period of institutional control, and over the long term period of performance is important for predicting the speciation and mobility of the redox sensitive radioactive and stable contaminants.

Both the SRS and Hanford waste streams contain soluble technetium which may require stabilization to meet disposal requirements. Technetium stabilization is a difficult problem because: 1) Tc is soluble and very mobile in the oxidized form( $\mathrm{Tc}(\mathrm{VII}) \mathrm{O}_{4}{ }^{-}$) typical of near surface environments, and 2) $\mathrm{Tc}-99$ is a long-lived isotope with a half-life of $2.1 \mathrm{E}+05$ years which poses a great challenge to prediction performance and places demanding requirements on the engineered barriers and environment to meet current regulatory disposal requirements.

A depth-discrete sampling and leaching method approach for measuring contaminant oxidation rate (effective contaminant specific oxidation rate) was used in this study. The method was modified by coating all sides of a cylindrical sample with an impermeable epoxy and then cutting a fresh surface 2 to $2.5 \mathrm{~cm}$ from the original top surface to eliminate sample inhomogeneity as the result of settling as a reason from observed results and provides 1-D soluble ion transport and gas transport information.

Based on nitrate (assumed to $100 \%$ soluble during curing and exposure and used as a reference) leaching results for the depth- discrete subsamples, regions depleted in nitrates were identified from the top surfaces to 9.5 and $3 \mathrm{~mm}$ into samples Tc2-9 (exposed to Hanford sediment) and Tc2-10 (DI water), respectively. Low mass fractions of nitrate were leached from these depth-discrete samples compared to samples further from the exposed surface presumably because a significant portion of the nitrate had already migrated into the soil or water, respectively. Depth-discrete subsample leaching results for $\mathrm{Na}$ can be interpreted in the same way over the same regions in the two samples tested.

Soluble Tc was leached from all of the depth-discrete subsamples from both Tc2-9 and Tc2-10 which strongly suggests that oxygen was present in the entire length of both samples. About 24 mass percent of the Tc in the original sample, was leached (soluble) from subsamples between 0.8 and $46 \mathrm{~mm}$ below the exposed surface of Tc2-9 (exposed to Hanford sediment). The same percent (24\%) was leached from the subsamples between 0.8 and $11 \mathrm{~mm}$ below the exposed surface of Tc2-10 (exposed to DI water). This suggests that the rate of oxygen migration into the sample exposed to soil was faster than the rate of migration into the sample exposed to water which is consistent with the more rapid transport of ions through a gas phase as compared to a liquid phase. It was assumed that moisture in the Hanford sediment was not sufficient to completely block the surface pores with respect to gas transport across the soil-waste form boundary or to block the transport or gas as efficiently as DI water.

Additional data are required to fully understand and quantify the progression of the region depleted in soluble ions and the rate of oxygen ingress and oxidation of redox sensitive contaminants such as Tc. However, these scoping studies have provided insights to the multiple mechanisms affecting the solubility and leachability of redox sensitive contaminants. 
In conclusion, leaching monolithic porous cementitious waste forms in water appears to be conservative for non-redox sensitive contaminants such as nitrate and sodium. However, leaching data obtained under saturated exposure conditions do not appear to be conservative for redox sensitive contaminants such as $\mathrm{Tc}(\mathrm{IV})$ phases which are easily and whose mobility is dependent on oxidation state. Leaching crushed samples in water still seems to be a conservative approach to estimating the concentrations of soluble contaminants in a waste form. 


\section{ABBREVIATIONS}

1-D

ASTM

DI

DOE

EPA

GGBFS

HTWOS

IC

ICP-OES

IDF

LAW

M

PNNL

RSD

SRNL

SRS

TDS

TT/QAP

WPT

w/cm
One dimensional

American Society of Testing and Materials

Deionized (water)

United States Department of Energy

United States Environmental Protection Agency

Ground Granulated Blast Furnace Slag

(Hanford) Tank Waste Operations System

Ion Chromatography

Inductively Coupled Plasma Optical Emission Spectrometer

(Hanford) Integrated Disposal Facility

Low Activity Waste

Molar

Pacific Northwest National Laboratory

Relative Standard Deviation

Savannah River National Laboratory

Savannah River Site

Total Dissolved Solids

Task Technical and Quality Assurance Plan

(Hanford) Waste Treatment and Immobilization Plant

Water to cementitious materials ratio 


\section{TABLE OF CONTENTS}

ACKNOWLEDGEMENTS...................................................................

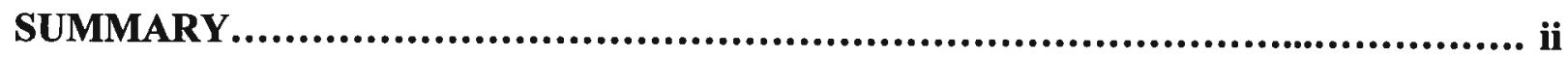

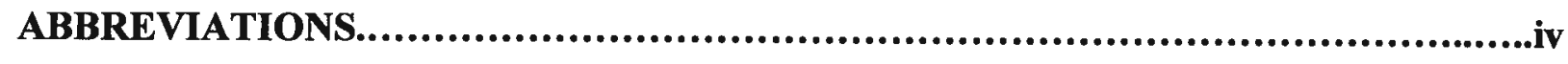

LIST OF TABLES..............................................................................

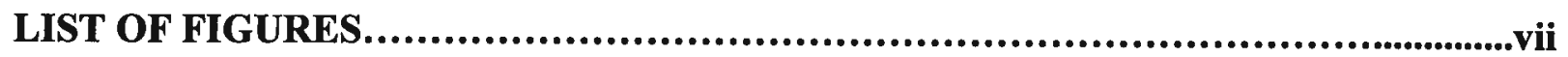

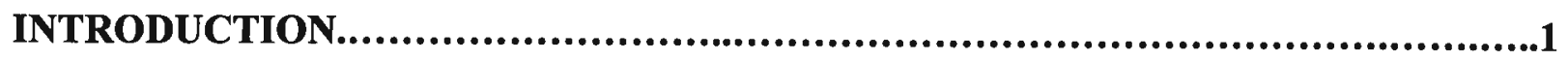

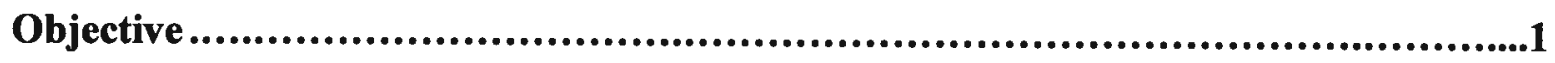

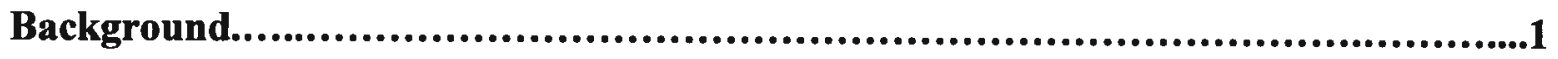

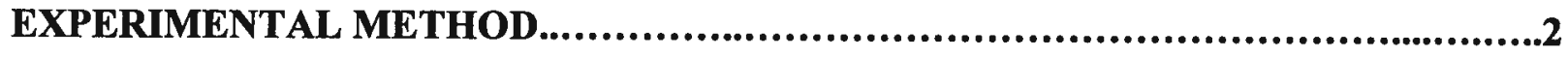

Waste Form Sample Preparation..........................................................2

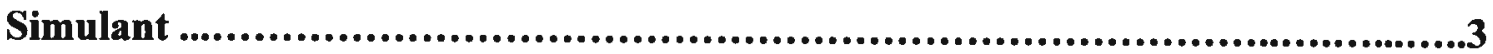

Cementitious reagents.......................................................................3

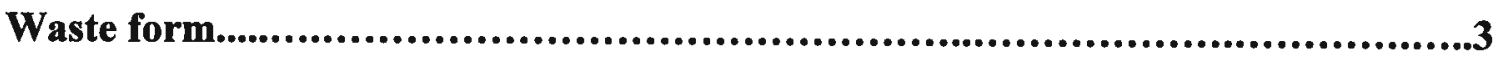

Waste Form Exposure Conditions .......................................................4

Waste Form Depth-Discrete Leaching....................................................5

Fraction leached.........................................................................5

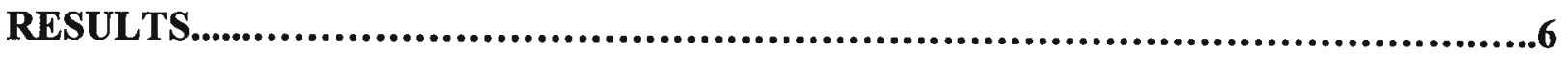

Tc-99 Leaching......................................................................66

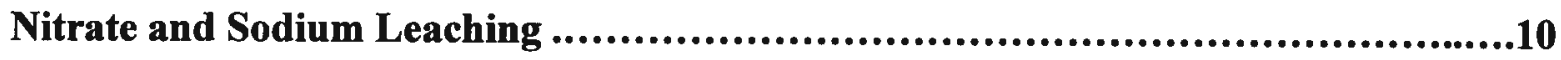

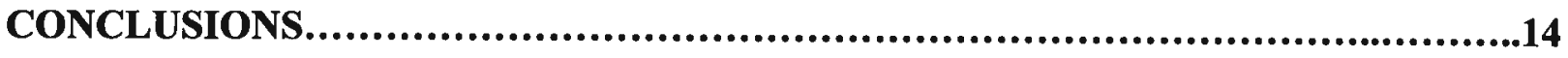

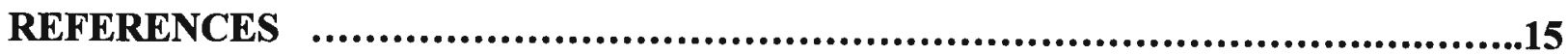

ATTACHMENT 1. CHARACTERIZATION OF AS_RECEIVED HANFORD SEDIMENT MOISTURE CONTENT AND SATURATED

MOISTURE CONTENT................................................16

ATTACHMENT 2. ANALYTICAL RESULTS FOR SUBSAMPLE

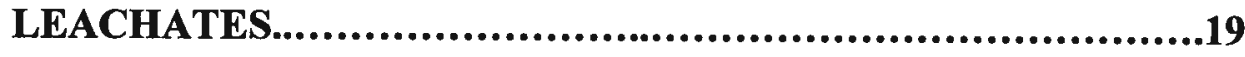




\section{LIST OF TABLES}

Table 1. LAW 5 M Simulant based on Hanford Tank Waste Operations Simulator (HTWOS) modeling [9]

Table 2. Ingredients and proportions of the $5 \mathrm{M} \mathrm{Na}$ simulant used to prepare the waste form..... 3

Table 3. Tc-99 spike added to the HTWOS Average $5 \mathrm{M}$ Na simulant [9]. .................................. 3

Table 4. Ingredients in Tc Spiked waste forms......................................................................... 3

Table 5. Summary of curing and exposure times. .................................................................... 4

Table 6. Tc-99 leachate results for depth-discrete subsample cut from Sample Tc2-9 cured in a humid environnement after which a 'freshly cut' surface was exposed to and leached in unsaturated Hanford sediment with 5 wt.\% moisture.

Table 7. Tc-99 leachate results for depth-discrete subsample cut from Sample Tc2-10 cured in a humid environnement after which a 'freshly cut' surface was exposed to and leached in DI water

Table 8. Na leachate results for depth discrete-subsample cut from Sample Tc2-9 cured in a humid environnement after which a 'freshly cut' surface was exposed to and leached in unsaturated Hanford sediment with 5 wt.\% moisture.

Table 9. $\mathrm{NO}_{3}$ leachate results for depth discrete-subsample cut from Sample Tc2-9 cured in a humid environnement after which a 'freshly cut' surface was exposed to and leached in DI water

Table 10. Na leachate results for depth-discrete subsample cut from Sample Tc2-10 cured in a humid environnement after which a 'freshly cut' surface was exposed to and leached in unsaturated Hanford sediment with 5 wt.\% moisture.

Table 11. $\mathrm{NO}_{3}{ }^{-}$leachate results for depth-discrete subsample cut from Sample Tc2-10 cured in a humid environnement after which a 'freshly cut' surface was exposed to and leached in unsaturated Hanford sediment with 5 wt.\% moisture.

Table 12. Summary of $\mathrm{NO}_{3}{ }^{-}, \mathrm{Na}$, and $\mathrm{Tc}$ leached as a function of distance from top surface of TC2-9 (exposed to Hanford sediment) and Tc2-10 (exposed to DI water).

Table 13. Cation and anion leachate results for depth discrete subsample cut from Sample Tc2-9 cured at ambient temperature in a humid environnement. The "fresh" top surface was subsequently exposed to and leached in unsaturated Hanford sediment with $5 \mathrm{wt} . \%$ moisture... 20

Table 14. Cation and anion leachate results for depth discrete subsample cut from Sample Tc2-10 cured at ambient temperature in a humid environnement. A "fresh" surface was subsequently exposed to and leached in DI water. 


\section{LIST OF FIGURES}

Figure 1. Epoxy coated sample with uncoated top surface, soil leaching media before sample was covered with about $3 \mathrm{~cm}$ of additional sediment, and container during exposure.. 4

Figure 2. Hanford sediment passing No. 18 sieve (left) and retained on No. 18 sieve (right)...... 5

Figure 3. Percent Tc-99 leached from depth-discrete subsamples as a function of distance from the as cast sample illustrating that the top portion was removed in order to expose a "fresh" surface to unsaturated Hanford sediment and DI water.

Figure 4. Percent Tc-99 leached from depth-discrete subsamples as a function of distance from fresh surfaces exposed to unsaturated Hanford sediment and DI water.

Figure 5. $\mathrm{Na}, \mathrm{NO}_{3}{ }^{-}$, and Tc-99 percents leached from depth-discrete subsamples as a function of distance from fresh surfaces exposed to unsaturated Hanford sediment and DI water. 


\section{INTRODUCTION}

Several U.S. DOE sites use or plan to use waste forms and/or concrete containment structures for radioactive waste disposal that are designed to have a chemically reducing environment to immobilize selected contaminants such as $\mathrm{Tc}(\mathrm{VII}) \mathrm{O}_{4}{ }^{-}$and $\mathrm{Cr}(\mathrm{VI}) \mathrm{O}_{4}{ }^{2-}$. These waste forms and containment structures are typically deployed in near surface unsaturated oxidizing environments. Consequently, the effect of exposure to air (oxygen) and water containing dissolved oxygen during production, during the period of institutional control, and over the long term period of performance is important for predicting the speciation and mobility of the redox sensitive radioactive and stable contaminants.

The rate of oxidation is important to the long-term performance of reducing salt waste forms because the solubility of some contaminants, e.g., technetium, is a function of oxidation state. $\mathrm{TcO}_{4}^{-}$in the salt solution is reduced to $\mathrm{Tc}(\mathrm{IV})$ and has been shown to react with ingredients in the waste form to precipitate low solubility sulfide and/or oxide phases [1,2, and 3]. Upon exposure to oxygen, the compounds containing $\mathrm{Tc}(\mathrm{IV})$ oxidize to the pertechnetate ion, $\mathrm{Tc}(\mathrm{VII}) \mathrm{O}_{4}^{-}$, which is highly soluble in water and aqueous solutions. Consequently the rate of technetium oxidation front advancement into a monolith and the technetium leaching profile as a function of depth from an exposed surface are important to waste form performance and ground water concentration predictions. The rate of oxidation front advancement into a monolith and the effect of oxygen ingress on redox sensitive contaminants are needed to:

1) Develop the conceptual model for performance predictions,

2) Provide data to parameterize fate and transport models, and

3) Validate computational codes.

\section{Objective}

The objectives of this study were to: utilize depth-discrete sampling and zero head space leaching to explore the effect of exposing cured waste forms to moist soil and DI water in a 1-D experimental configuration. More specifically, the effect of these exposure conditions on Tc leachability as a function of distance from the exposed surface was determined.

\section{Background}

Low temperature waste forms are currently being used and considered for solidification of low-level radioactive wastes across the DOE complex. Examples include saltstone, a cementitious waste form used at the Savannah River Site (SRS) to immobilize low-activity sodium salt waste, and Cast Stone which was recently selected for solidification of secondary waste from the Hanford Tank Waste Treatment and Immobilization Plant (WTP). Cast Stone is also being considered to provide supplemental Low Activity Waste (LAW) immobilization capacity for the Hanford site.

Both the SRS and Hanford waste streams contain soluble technetium which may require stabilization to meet disposal requirements. Technetium stabilization is a difficult problem because: 1) Tc is soluble and very mobile in the oxidized form typical of near surface environments, and 2) Tc-99 is a long-lived isotope with a half-life of $2.1 \mathrm{E}+05$ years which poses a great challenge to prediction performance and places demanding requirements on the engineered barriers and environment to meet current regulatory disposal requirements.

Cast Stone and saltstone contain portland cement and fly ash in addition to ground granulated blast furnace slag (GGBFS). These hydraulic and pozzolanic ingredients react with water and other constituents in the waste stream to form the waste form matrix. The GGBFS stabilizes (reduces mobility) redox sensitive contaminants, such as, $\mathrm{Tc}$ and $\mathrm{Cr}$. In a high $\mathrm{pH}$ environment, GGBFS chemically reduces 
pertechnetate, $\mathrm{Tc}(\mathrm{VII}) \mathrm{O}_{4}^{-}$, to the less soluble $\mathrm{Tc}(\mathrm{IV})$ oxidation state. ${ }^{1}$ Over time, oxygen in the air, soil pore gas, and oxygen dissolved in the vadose zone pore water can oxidize the waste form and re-oxidize the Tc(IV) to the highly soluble Tc(VII) form.

An understanding of factors that affect the oxidation state of redox sensitive contaminants stabilized in cementitious waste forms is required to improve waste forms and engineered barriers for shallow land disposal. In addition, the parameters and relationships for the 1) rate of bulk matrix oxidation and 2) potential for and efficiency of re-reduction of soluble Tc in cured un-oxidized portions of waste forms are required for predicting long-term performance.

\section{EXPERIMENTAL METHOD}

A method for measuring contaminant oxidation fronts for redox sensitive contaminants in cementitious waste forms containing GGBFS was recently developed at the Savannah River National Laboratory (SRNL) $[4,5$, and 6]. This method is based upon leaching depth-discrete subsamples obtained as a function of distance from an exposed surface. Leaching is performed in a zero head space container using deionized, de-aerated water to minimize oxidation during the leaching process. Leaching time was $48 \pm 4$ hours.

\section{Waste Form Sample Preparation}

Simulant. The Hanford Tank Waste Operations System (HTWOS) "Average" 5 M Na simulant was used rather than the CBP reference waste form [7] because the materials are very similar and the Tcspiked cast stone samples were already prepared. The composition was derived from an overall average of the 1046 weeks of modeled LAW feed to a supplemental immobilization facility over a 20 year mission and is referred to as the HTWOS "Average" $5 \mathrm{M}$ Na simulant $[8,9,10]$. The overall average concentrations in this simulant are listed in Table 1. The ingredients and proportions in the $5 \mathrm{M} \mathrm{Na}$ simulated are provided in Table 2. Compounds were added to the liquid in the order they are listed in Table 2. Tc-99 was added to the $5 \mathrm{M}$ Na simulant prior to addition of the premixed reagents as $\mathrm{NH}_{4} \mathrm{TcO}_{4}$ as indicated in Table 3.

Table 1. LAW 5 M Simulant based on Hanford Tank Waste Operations Simulator (HTWOS) modeling [9].

\begin{tabular}{|c|c|c|c|}
\hline \multirow{2}{*}{ Waste Constituent } & \multicolumn{3}{|c|}{ HTWOS Overall Average Concentration } \\
\cline { 2 - 4 } & $(\mathbf{m o l e s} / \mathbf{L})$ & $(\mathbf{g} / \mathbf{L})$ & $(\mathbf{m g} / \mathbf{g})^{*}$ \\
\hline $\mathrm{Na}$ & 5.000 & 115.00 & 93.50 \\
\hline $\mathrm{K}$ & 0.03 & 1.28 & 1.04 \\
\hline $\mathrm{Al}$ & 0.31 & 8.28 & 6.73 \\
\hline $\mathrm{Cl}$ & 0.04 & 1.5 & 1.22 \\
\hline $\mathrm{F}$ & 0.030 & 0.6 & 0.49 \\
\hline $\mathrm{S}$ & 0.090 & 2.74 & 2.23 \\
\hline $\mathrm{P}$ & 0.050 & 1.52 & 1.24 \\
\hline $\mathrm{NO} 2$ & 0.57 & 26 & 21.14 \\
\hline $\mathrm{NO} 3$ & 1.63 & 101 & 82.11 \\
\hline $\mathrm{CO} 3$ & 0.27 & 16.5 & 13.41 \\
\hline $\mathrm{OH}$ & 1.56 & 26.5 & 21.54 \\
\hline
\end{tabular}

* $1 \mathrm{ml} 5 \mathrm{M}$ Na simulant $=1.230 \mathrm{~g} 5 \mathrm{M}$ simulant. 1 gram of Cast Stone made with $5 \mathrm{M}$ Na simulate and a water to cementitious solids ratio $=0.60$ contains $0.451 \mathrm{~g} 5 \mathrm{M} \mathrm{Na}$ simulant.

\footnotetext{
${ }^{1}$ The fraction of pertechnetate chemically reduced to the less soluble $\mathrm{Tc}(\mathrm{VI})$ oxidation state depends on several factors including the: initial concentration, initial chemical form (inorganic or organic), and chemistry of the waste form and waste form pore solution.
} 
Table 2. Ingredients and proportions of the $5 \mathrm{M}$ Na simulant used to prepare the waste form.

\begin{tabular}{|l|c|}
\hline Compound & Amount (g / L) \\
\hline Water & 819.50 \\
\hline $\mathrm{Al}\left(\mathrm{NO}_{3}\right)_{3} \cdot 9 \mathrm{H}_{2} \mathrm{O}$ & 115.165 \\
\hline $50 \%$ by Weight $\mathrm{NaOH}$ & 223.04 \\
\hline $\mathrm{Na}_{2} \mathrm{SO}_{4}$ & 12.215 \\
\hline $\mathrm{Na}_{3} \mathrm{PO}_{4} \cdot 12 \mathrm{H}_{2} \mathrm{O}$ & 18.5 \\
\hline $\mathrm{NaCH}_{3} \mathrm{COO} \cdot 3 \mathrm{H}_{2} \mathrm{O}$ & 5.25 \\
\hline $\mathrm{Na}_{2} \mathrm{CO}_{3}$ & 29.05 \\
\hline $\mathrm{NaNO}_{3}$ & 56.79 \\
\hline $\mathrm{NaNO}_{2}$ & 38.975 \\
\hline $\mathrm{NaCl}^{\mathrm{NaF}}$ & 2.48 \\
\hline $\mathrm{NaF}$ & 1.35 \\
\hline $\mathrm{KNO}$ & 3.33 \\
\hline \hline Density & 1.230 \\
\hline Wt. $\%$ Solids & 27.06 \\
\hline
\end{tabular}

Table 3. Tc-99 spike added to the HTWOS Average 5 M Na simulant [9].

\begin{tabular}{|c|c|c|c|c|c|c|c|}
\hline $\begin{array}{l}\text { Cast } \\
\text { Stone } \\
\text { w/cm } \\
\end{array}$ & $\begin{array}{c}\text { Average 5 M Na } \\
\text { Simulant Tc-99 } \\
\text { Concentration* } \\
(\mu \mathrm{Ci} / \mathrm{L}) \\
\end{array}$ & $\begin{array}{l}\text { Waste } \\
\text { form } \\
\text { Batch } \\
\text { Size } \\
\text { (g) } \\
\end{array}$ & $\begin{array}{c}\text { 5M Na } \\
\text { Average } \\
\text { Simulant } \\
\text { (g) }\end{array}$ & $\begin{array}{c}5 \mathrm{M} \text { Na } \\
\text { Average } \\
\text { Simulant } \\
(\mathrm{mI})\end{array}$ & $\begin{array}{c}\mathrm{NH}_{4} \mathrm{TcO}_{4} \\
0.5 \mathrm{mCi} / \mathrm{ml} \\
\text { Stock } \\
\text { Solution } \\
(\mathrm{ml}) \\
\end{array}$ & $\begin{array}{l}\text { 8:47:45 } \\
\text { Cement : } \\
\text { slag : } \\
\text { fly ash } \\
\text { Blend } \\
\text { (g) }\end{array}$ & \begin{tabular}{|c|}
$5 \mathrm{M}$ \\
Waste form \\
Tc-99 \\
Concentration \\
$\boldsymbol{\mu C i} / \mathrm{g})$ \\
\end{tabular} \\
\hline 0.60 & 189 & 1800 & 812.5 & 660.57 & $\begin{array}{c}0.25 \\
(250 \mu \mathrm{L})\end{array}$ & 987.5 & 0.0694 \\
\hline
\end{tabular}

* The HTWOS estimated maximum concentration for Tc-99 is $4.13 \mathrm{E}-05 \mathrm{Ci} / \mathrm{moles}$ of Na. For $5 \mathrm{M} \mathrm{Na}$ simulant, the maximum Tc-99 value is $20.58 \mathrm{E}-05 \mathrm{Ci}$ per liter of simulant $(205.8 \mathrm{uCi} / \mathrm{L})$.

Cementitious reagents. The cement, blast furnace slag, and fly ash used in this study were obtained from a supplier in the Hanford area via PNNL and were shipped to SRNL. The three cementitious materials were pre mixed in the following proportions: portland cement : slag : fly ash ratios of 8:47:45 by mass manually shaking the bags. The cementitious materials were supplied by Hanford personnel.

Waste form. An $1800 \mathrm{~g}$ batch of the waste form was prepared with a water to cementitious reagent ratio $(w / \mathrm{cm})=0.60$. See Table 4. The ingredients and proportions are shown in Table 3. The waste form slurry was mixed for 3 minutes before being transferred to $90 \times 35 \mathrm{~mm}$ cylindrical containers. Ingredients in a $1000 \mathrm{~g}$ batch of cementitious waste form are shown in Table 3. The containers were filled to the top to the extent possible and capped. They were placed in an overpack container with moist towels for and cured for 103 days at ambient temperature (about $22^{\circ} \mathrm{C}$ ) and $65 \%$ to $75 \%$ relative humidity.

Table 4. Ingredients in Tc Spiked waste forms.

\begin{tabular}{|c|c|c|c|c|}
\hline Batch Size (g) & Cement (g) & Slag (g) & Fly ash (g) & Simulant (g) \\
\hline $\mathbf{1 8 0 0}$ & $\mathbf{7 9}$ & 464.1 & 444.4 & $\mathbf{8 1 2 . 5}$ \\
\hline
\end{tabular}




\section{Waste Form Exposure Conditions}

Two samples, Tc2-9 and Tc2-10, were removed from the curing containers and exposed to moist Hanford sediment and DI water, respectively. Both samples were coated with 3 layers of epoxy on all sides. After the epoxy hardened which took about $3 \mathrm{hr}$., the top $2.5 \mathrm{~cm}$ and $2.2 \mathrm{~cm}$ were removed from samples Tc2-9 and Tc2-10, respectively, so that a "fresh" surface would be in contact with either DI water or as received Hanford soil. Sample Tc2-9 was placed in a container containing sieved Hanford sediment and then covered with about $3 \mathrm{~cm}$ of additional sediment. Sample Tc2-10 was placed in a container with DI water. Both containers had air space above the exposure media. Lids were placed on the containers and they were returned to secondary containment trays in a rad hood. See Figure 1. A summary of the curing and exposure times is provided in Table 5.

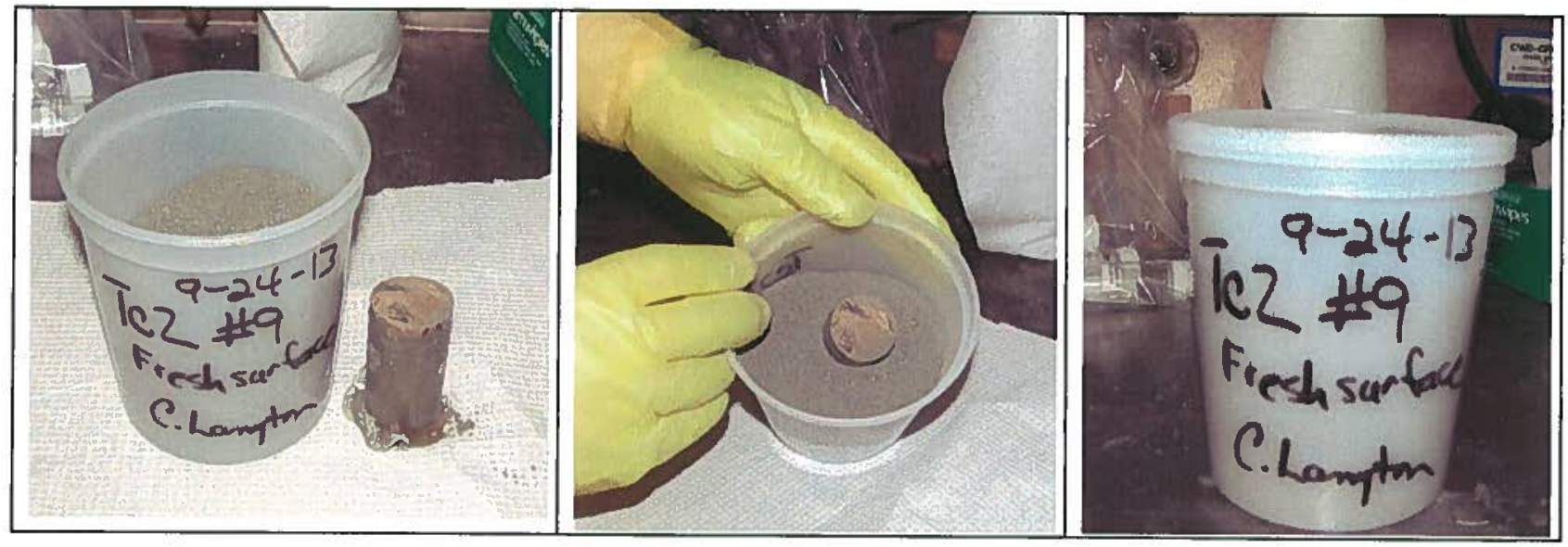

Figure 1. Epoxy coated sample with uncoated top surface, soil leaching media before sample was covered with about $3 \mathrm{~cm}$ of additional sediment, and container during exposure.

Table 5. Summary of curing and exposure times.

\begin{tabular}{|l|c|c|c|c|c|}
\hline Sample & Prepared & $\begin{array}{c}\text { Cured in Sealed } \\
\text { Container } \\
\text { (days) }\end{array}$ & Exposure Condition & $\begin{array}{c}\text { Exposure } \\
\text { Time } \\
\text { (days) }\end{array}$ & $\begin{array}{c}\text { Total } \\
\text { Age } \\
\text { (days) }\end{array}$ \\
\hline Tc2-9 & $6-3-13$ & 113 & Hanford soil: 9-24-13 to 2-25-14 & 154 & 267 \\
\hline Tc2-10 & $6-3-13$ & 113 & DI water: 9-24-13 to 2-25-14 & 154 & 267 \\
\hline
\end{tabular}

The Hanford sediment was collected in 2010 from an elevation consistent with the elevation of the sediment exposed in the Integrated Disposal Facility (IDF) [11]. The sediment was sent to SRNL by D. Wellman, PNNL, in the spring of 2013. Material from three 5-gallon buckets, Buckets 17, 18, and $19^{2}$ was sieved through a No. $18(1 \mathrm{~mm})$ sieve and homogenized. The as-received moisture content of the sieved material was determined by drying at $110^{\circ} \mathrm{C}$ and found to be $4.9 \mathrm{wt}$. \%. (The saturated moisture content for the composite sieved sample was determined to be $9.5 \mathrm{wt}$ \% based on moisture-density relationship for a maximum dry density of $134.4 \mathrm{lbs} / \mathrm{cu}$.ft.) See Attachment 1 . The material was stored in a plastic 5 gallon bucket with a lid. The sieved sediment is shown in Figure 2 (left). The coarse fraction retained on the sieve is shown in Figure 2 (right). The coarse fraction was not used in the exposure test.

\footnotetext{
${ }^{2}$ Information accompanying Buckets 17, 18, and 19 provided detailed location information C7536 I020-B24P34, C7536 I-021 B24P35, C7536 I-026 B24P40, respectively. All of the material was collected from Well: 299-E13114: C7536: 200E.
} 

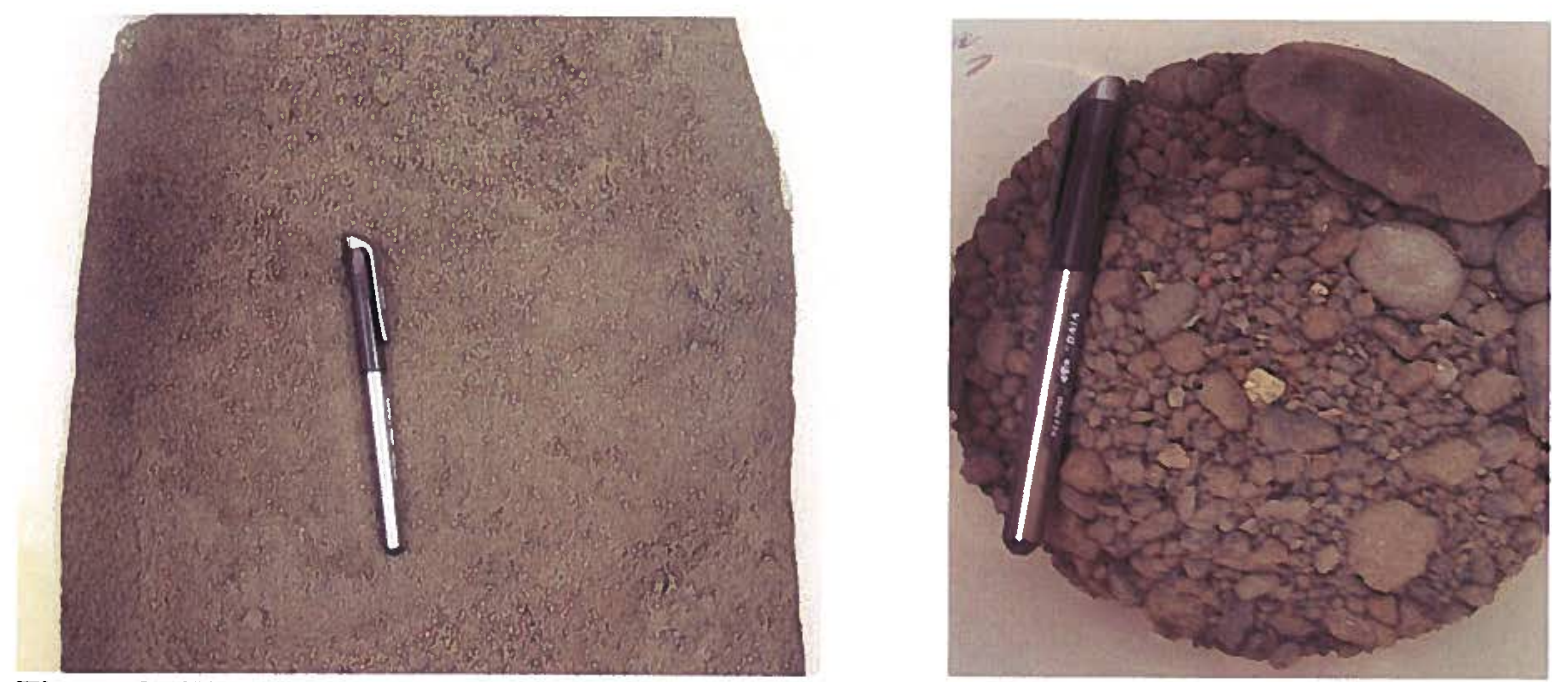

Figure 2. Hanford sediment passing No. 18 sieve (left) and retained on No. 18 sieve (right).

\section{Waste Form Depth Discrete Leaching}

The details of the sampling and leaching methods are described elsewhere [5, 6, and 7]. In summary, layers of the waste form from 2 to over $20 \mathrm{~mm}$ were removed from the cylindrical monoliths starting at the top exposed surface. The wafers were size reduced in air (crushed to a powder) with a mortar and pestle. A short term leach test based on EPA 1311 was used [12]. All or a portion of the crushed wafer was weighed and placed in a leaching container. The time required for crushing, weighing and covering each sub- sample with leachate was less than 10 minutes. Deionized, de-aerated ASTM Type I/II water was used as the leachate. Zero head space leaching containers were used to minimize exposure to oxygen and sample oxidation during leaching. The filled leach vessels were loaded into a large mouth plastic bottle which was tumbled end-over-end at $30 \mathrm{rpm}$ for $48 \pm 2$ hours.

After tumbling, leachates were filtered using 0.45 micron filters attached to $20 \mathrm{~mL}$ syringes. $\mathrm{Ca}, \mathrm{K}, \mathrm{Al}$, and $\mathrm{Na}$ concentrations were measured using an Inductively Coupled Plasma- Optical Emission Spectrometer (ICP-OES), Varian 730-ES. $\mathrm{NO}_{3}^{-}, \mathrm{NO}_{2}{ }^{-}$, and $\mathrm{SO}_{4}{ }^{2-}$ were analyzed using Ion Chromatography (IC), Dionex ICS-5000 EG. Tc-99 was analyzed by liquid scintillation. Sample preparation and the appearance of the leachates before tumbling and after filtering are illustrated in earlier reports [5 and 6]. Leaching results for all analytes are tabulated in Attachment 2.

Fraction Leached. The fraction of selected anions and cations leached or percent leached (fraction leached X 100) from each crushed subsample was selected as the parameter for indicating 1) the effect of exposure to air (i.e., oxidation) on the redox sensitive contaminants such as $\mathrm{TcO}_{4}{ }^{-}$and $\mathrm{CrO}_{4}{ }^{2-}, \mathrm{Na}$ and $\mathrm{NO}_{3}{ }^{-}$and 2 ) the depth of penetration of oxygen into the waste form (i.e., rate of oxidation front advancement). The percent leached was calculated using Equation 1.

\section{Equation 1. \% Leached $=100 *\left(\frac{\mathrm{m}_{\mathrm{i}-\text { leachate }}}{\mathrm{m}_{\mathrm{i} \text {-total in solid }}}\right)$}

Where:

$m_{i-l e a c h e d}=$ mass of species i leached $(\mathrm{mg})$. The leachate was filtered prior to analysis using a $0.45 \mu \mathrm{m}$ filter.

$\mathbf{M}_{\mathrm{i} \text {-total }}=$ mass of species $\mathrm{i}$ in the subsample leached (mg). The total amount in the waste form was approximated and only reflects the contribution to the waste form from the spiked mixing solution. 


\section{RESULTS}

Two samples, Tc2-9 and Tc2-10 with identical curing histories were coated with epoxy and the top 25 to $22 \mathrm{~mm}$ were removed from the samples to achieve a "fresh" cut surfaces. See Figure 3. Sample Tc2-9 was exposed to Hanford sediment with $4.5 \%$ moisture (as received condition). Sample Tc2-10 was exposed to DI water. After exposure for 154 days, the depth-discrete subsamples were cut, crushed and leached in deaerated, DI water in zero head space container.

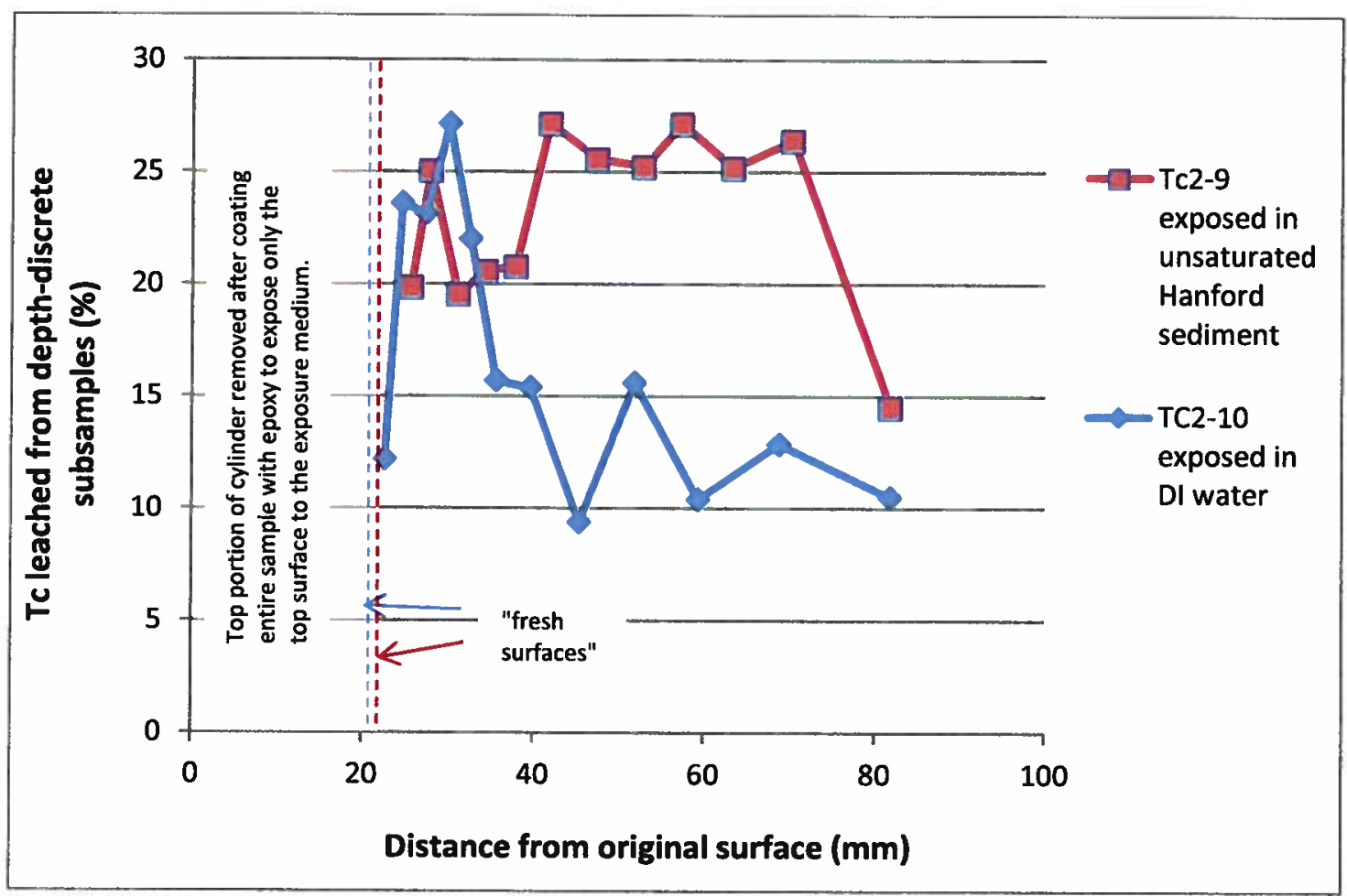

Figure 3. Percent Tc-99 leached from depth-discrete subsamples as a function of distance from the as cast sample illustrating that the top portion was removed in order to expose a "fresh" surface to unsaturated Hanford sediment and DI water.

\section{Tc-99 Leaching}

Tc-99 leachate results are provided in Tables 6 and 7, respectively. Results are re-plotted in Figure 4 as a function of the "fresh surface" sample. Subsample leaching results from the top 10 to $15 \mathrm{~mm}$ of the "fresh" cut surfaces of both samples showed an initial depletion and then a spike in the mass fraction Tc99. The spike was more apparent for the sample exposed to DI water.

The Tc fraction leached from depth-discrete subsamples of Tc2-9 (exposed to Hanford sediment) dropped back to the value measured for the surface subsample between about 3 and $12 \mathrm{~mm}$ before increasing to 0.25 to 0.27 . The mass fraction Tc-99 leached from bottom subsample (16mm thick) dropped to the lowest value measured, 0.145 , and may indicate the oxidation front resulting from exposure in soil.

The Tc-99 mass fraction leached from depth-discrete subsamples of Tc2-10 (exposed to DI water) dropped to 0.09 to 0.16 between 12 and $65 \mathrm{~mm}$ below the exposed surface. The leveling off of the 
leachable Tc below $12 \mathrm{~mm}$ may indicate the location of the oxidation front resulting from oxygen supplied to the fresh cut surface by the DI water.

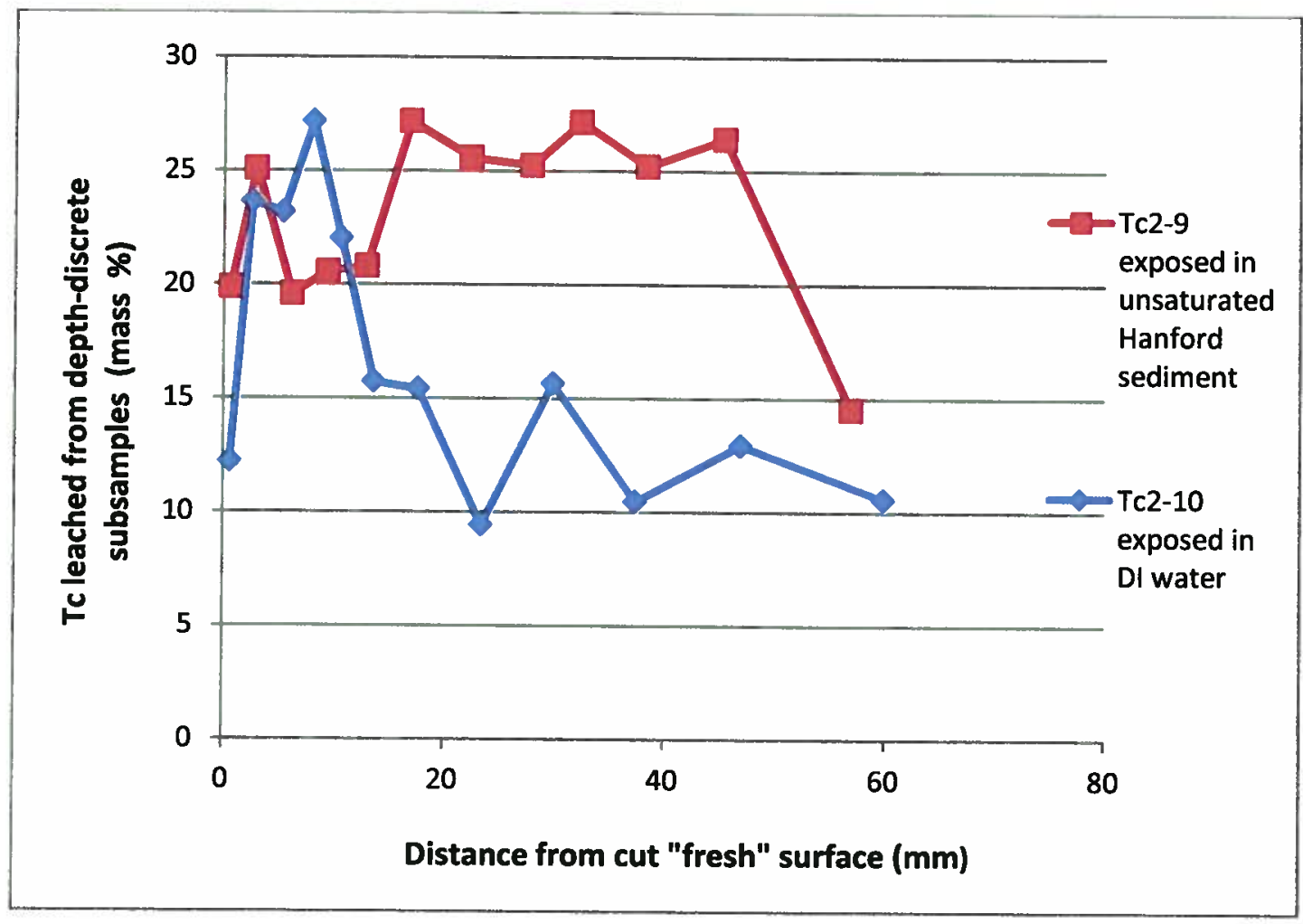

Figure 4. Percent Tc-99 leached from depth-discrete subsamples as a function of distance from fresh surfaces exposed to unsaturated Hanford sediment and DI water.

The lowest Tc-99 mass fractions leached from Tc2-9 and Tc2-10 subsamples were 0.155 and 0.094 , respectively. Soluble Tc-99 throughout the entire length of these samples may be due to one or several of the following:

- Oxidation during exposure to Hanford unsaturated soil (Tc2-9) and DI water (Tc2-10).

- Oxidation during the subsampling, grinding, weighing, and leaching process. (Previous results indicate that $\leq 5 \% \mathrm{t}$ of the Tc oxidized during sample handling and leaching [6]).

- Incomplete reduction of the Tc(IV) by the waste form.

- Movement of re-oxidized Tc throughout the sample during curing and exposure.

- Incomplete isolation of all surfaces of the cylindrical samples with respect to oxygen. Only the top surface was intended to be exposed to the environmental media. 


\begin{tabular}{|c|c|c|c|c|c|c|c|c|}
\hline 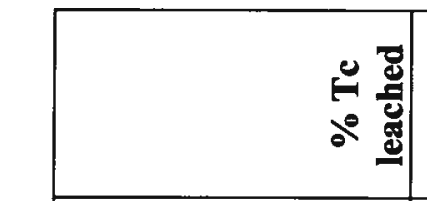 & 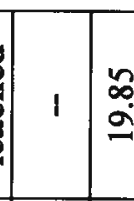 & 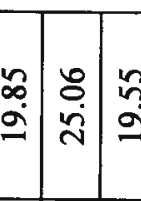 & 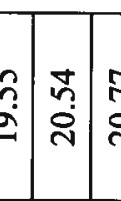 & 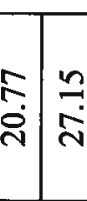 & 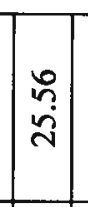 & สิธี่ & & $\mid$ \\
\hline 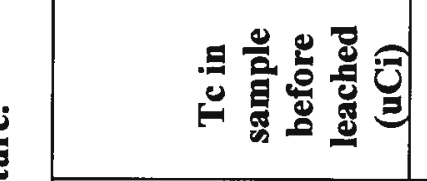 & 章 & 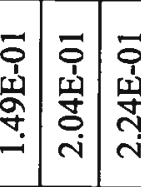 & 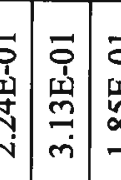 & & 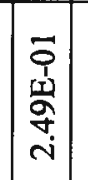 & & & 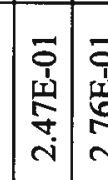 \\
\hline ? & 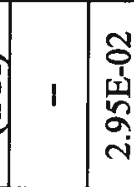 & 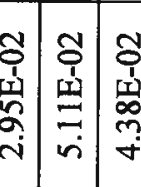 & 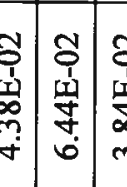 & & 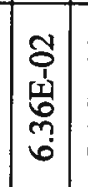 & 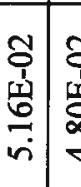 & & $\left|\begin{array}{c}0 \\
0 \\
\tilde{\omega} \\
\vdots \\
0 \\
0\end{array}\right|$ \\
\hline 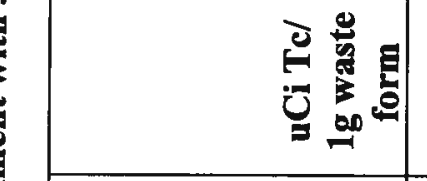 & 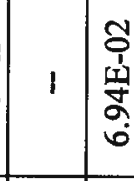 & 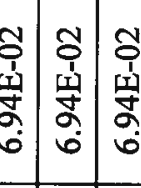 & $\begin{array}{c}n \\
\vdots \\
0\end{array}$ & 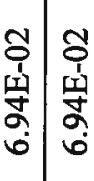 & $\mid$ & 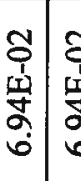 & & 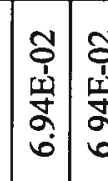 \\
\hline 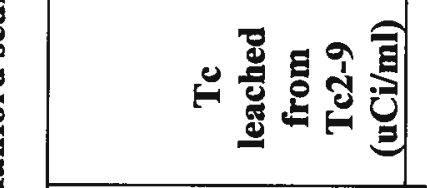 & & 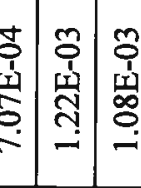 & 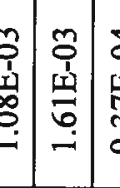 & & $\begin{array}{c}0 \\
0 \\
0 \\
0 \\
0\end{array}$ & & & $\mid$ \\
\hline & & 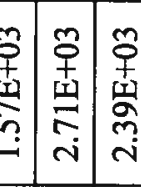 & 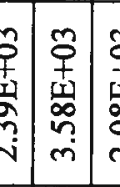 & & & & & 勇 \\
\hline & & 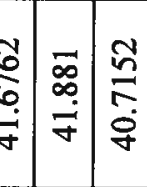 & $\begin{array}{c}0 \\
0\end{array}$ & & $\left|\begin{array}{l}\mid \\
0 \\
0 \\
o \\
\dot{q}\end{array}\right|$ & & & $\mid$ \\
\hline 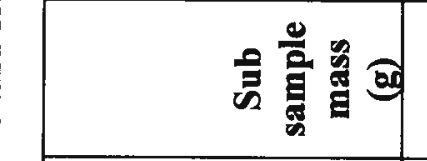 & & 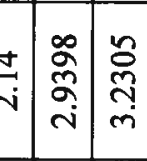 & 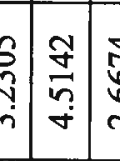 & 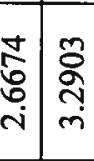 & $\mid \begin{array}{c}\infty \\
\substack{\infty \\
0 \\
\infty \\
\infty} \\
c\end{array}$ & 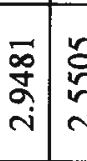 & & $\mid$ \\
\hline 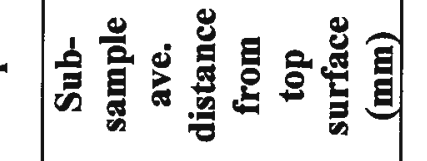 & 10 & $=0$ & 60 & $\stackrel{0}{=}:$ & 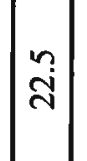 & 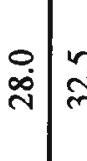 & & \\
\hline 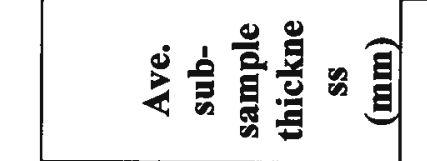 & 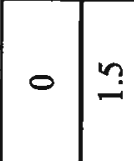 & $=m$ & & & & 4 & & \\
\hline 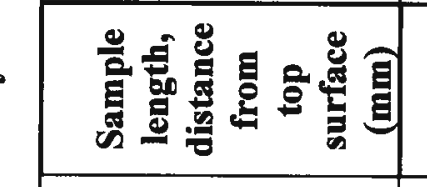 & & 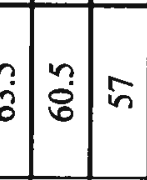 & $n$ & 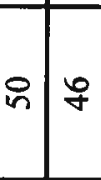 & & & & $\simeq$ \\
\hline केष & & & & & & & & - \\
\hline
\end{tabular}




\begin{tabular}{|c|c|c|}
\hline 党! & \multicolumn{2}{|c|}{ 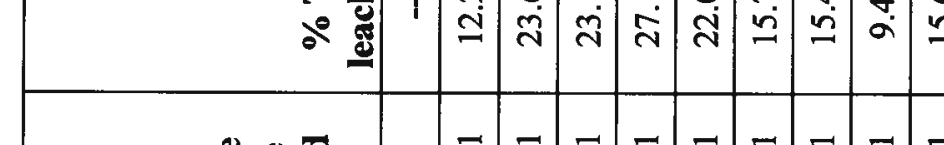 } \\
\hline 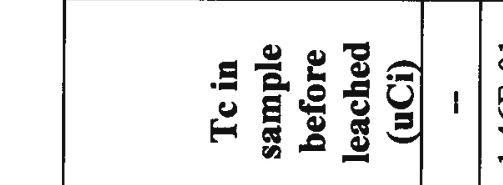 & 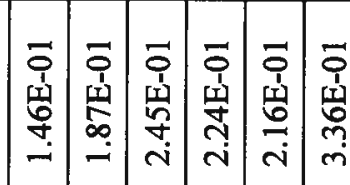 & 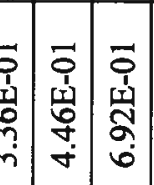 \\
\hline 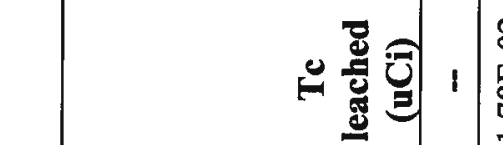 & 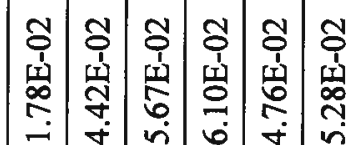 & \\
\hline 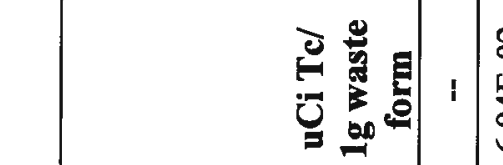 & 18: & \\
\hline 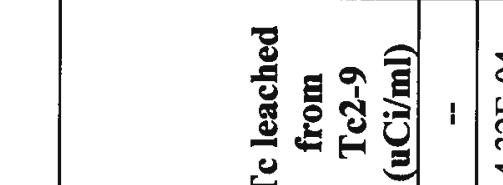 & 亩 & \\
\hline 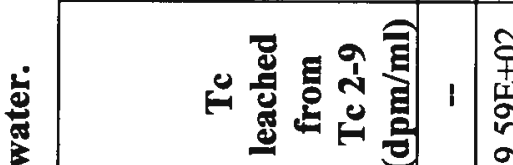 & 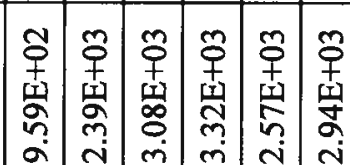 & \\
\hline 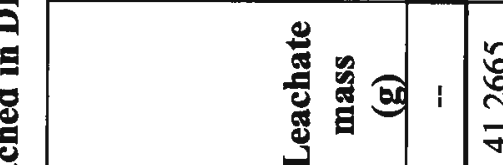 & 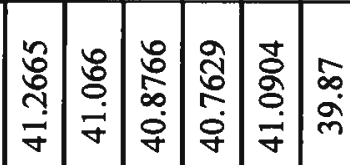 & \\
\hline 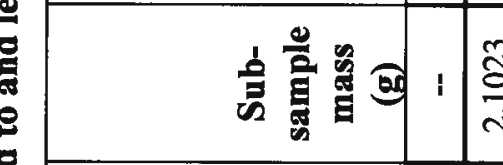 & & \\
\hline 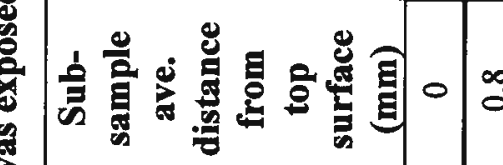 & $\infty$ & \\
\hline 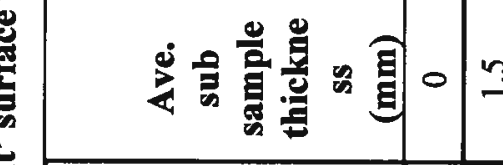 & & \\
\hline 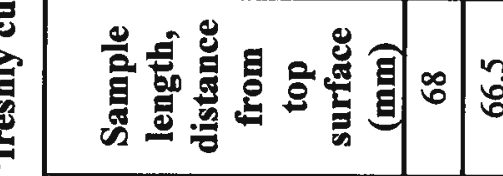 & & \\
\hline 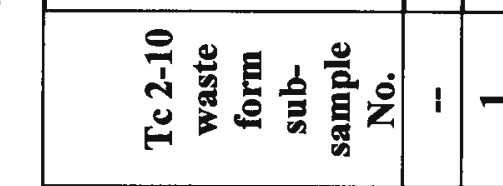 & & \\
\hline
\end{tabular}




\section{Nitrate and Sodium Leaching}

Nitrate and sodium are not redox sensitive species under the curing and exposure conditions of this test. Depth-discrete subsamples leachate results for sodium and nitrate are provided in Tables 8 to 11 and are plotted in Figure 4 for comparison with technetium, a redox sensitive radionuclide. Nitrate is not bound in any low solubility solid phases. However, a portion of the sodium is thought to be bound in calcium silicate hydrate phases and calcium aluminate hydrate phases [Langton, 2014] and is therefore not completely soluble.

An initial depletion in leachable nitrate and sodium is more obvious for these species than for Tc. The $\mathrm{NO}_{3}{ }^{-}$and $\mathrm{Na}$ mass fractions leached from depth-discrete subsamples below about 10 to $15 \mathrm{~mm}$ showed a slight downward trend from about $15 \mathrm{~mm}$ to the final bottom subsample.

Slightly higher mass fractions of $\mathrm{Na}$ and $\mathrm{NO}_{3}{ }^{-}$were leached from depth-discrete subsamples of samples Tc2-9 (exposed to Hanford sediment) below about $15 \mathrm{~mm}$ than from corresponding depth-discrete samples of Tc2-10 (cured in Hanford sediment). Somewhat higher fractions of $\mathrm{Na}$ were leached from the Tc2-9 (exposed to sediment) subsamples than from Tc2-10 which was exposed to DI water. The reverse was found for $\mathrm{NO}_{3}^{-}$. Higher fractions of NO3- were leached from subsamples of Tc2-10 (exposed to DI water) when compared to subsamples of Tc2-9 (exposed to moist Hanford sediment).

The low $\mathrm{Na}$ and $\mathrm{NO}_{3}{ }^{-}$mass fractions leached from the near surface subsamples of $\mathrm{Tc} 2-9$ and $\mathrm{Tc} 2-10$ strongly suggests that the top portions of these samples were depleted in $\mathrm{Na}$, and $\mathrm{NO}_{3}{ }^{-}$prior to the depthdiscrete sampling due to migration of these soluble ions into the exposure media. Consequently the actual mass of these ions in the uppermost depth-discrete subsamples after exposure was less than the mass calculated for the original material.

Based on the mass fraction of nitrate leached (assumed to be $100 \%$ soluble throughout the curing and exposure), the depth of depletion in Tc2-9 (exposed to Hanford sediment) was about $9.5 \mathrm{~mm}$ and in Tc210 exposed to DI water it was about $3 \mathrm{~mm}$. Inhomogeneity due to settling or surface effects resulting from sample preparation is unlikely in these samples because the top 2.2 to $2.5 \mathrm{~cm}$ of the as cast sample was removed within a few minutes prior to exposure.

In addition, about 24 percent of the Tc-99 in the subsamples of Tc2-9 (exposed to Hanford sediment) between 0.8 and $46 \mathrm{~mm}$ was extracted in the depth-discrete leaching test. About 24 percent of the Tc-99 in the subsamples of Tc2-10 (exposed to DI water) was extracted between 0.8 and $11 \mathrm{~mm}$. This is about $2 \mathrm{X}$ as much as was leached from the lower portions of both samples. These data suggest that oxidation of the reduced Tc species extended further into the sample exposed to unsaturated Hanford sediment compared to the samples exposed to DI water. A summary of the fractions $\mathrm{Na}, \mathrm{NO}_{3}{ }^{-}$and $\mathrm{Tc}$ leached as a function of distance from the exposed surfaces of Tc2-9 and Tc2-10 is provided in Table 12. 
Table 8. Na leachate results for depth discrete-subsample cut from Sample Tc2-9 cured in a humid environnement after which a 'freshly cut' surface was exposed to and leached in unsaturated Hanford sediment with 5 wt.\% moisture.

\begin{tabular}{|c|c|c|c|c|c|c|c|c|}
\hline $\begin{array}{c}\text { Te 2-9 } \\
\text { waste form } \\
\text { sub- } \\
\text { sample } \\
\text { no. }\end{array}$ & $\begin{array}{c}\text { Ave. } \\
\text { distance } \\
\text { from } \\
\text { top surface } \\
\text { (mm) }\end{array}$ & $\begin{array}{c}\text { Sub- } \\
\text { sample } \\
\text { mass (g) }\end{array}$ & $\begin{array}{c}\text { Leachate } \\
\text { mass } \\
\text { (g or ml) }\end{array}$ & $\begin{array}{c}\text { Na } \\
\text { leached } \\
\text { from } \\
\text { Tc 2-9 } \\
\text { (mg/L) }\end{array}$ & $\begin{array}{c}\text { Na } \\
\text { in 1g } \\
\text { waste } \\
\text { form } \\
\text { (mg) }\end{array}$ & $\begin{array}{c}\text { Na } \\
\text { Leached } \\
\text { (mg) }\end{array}$ & $\begin{array}{c}\text { Na in } \\
\text { sample } \\
\text { before } \\
\text { leached } \\
\text { (mg) }\end{array}$ & $\begin{array}{c}\text { \% Na } \\
\text { leached }\end{array}$ \\
\hline $\mathbf{1}$ & $\mathbf{0 . 8}$ & 2.14 & 41.6762 & $\mathbf{8 9 8}$ & 42.07 & 37.43 & 90.03 & 41.57 \\
\hline $\mathbf{2}$ & 3 & 2.9398 & 41.881 & 1750 & 42.07 & 73.29 & 123.68 & 59.26 \\
\hline $\mathbf{3}$ & $\mathbf{6 . 3}$ & 3.2305 & 40.7152 & 2630 & 42.07 & 107.08 & 135.91 & 78.79 \\
\hline $\mathbf{4}$ & 9.5 & 4.5142 & 39.9093 & 2600 & 42.07 & 103.76 & 189.91 & 54.64 \\
\hline $\mathbf{5}$ & 13 & 2.6674 & 41.0332 & 2550 & 42.07 & 104.63 & 112.22 & 93.24 \\
\hline $\mathbf{6}$ & 17 & 3.2903 & 40.5942 & 3160 & 42.07 & 128.28 & 138.42 & 92.67 \\
\hline $\mathbf{7}$ & 22.5 & 3.5838 & 40.7836 & 3380 & 42.07 & 137.85 & 150.77 & 91.43 \\
\hline $\mathbf{8}$ & 28 & 2.9481 & 41.5034 & 2830 & 42.07 & 117.45 & 124.03 & 94.70 \\
\hline $\mathbf{9}$ & 32.5 & 2.5505 & 39.7714 & 2380 & 42.07 & 94.66 & 107.30 & 88.22 \\
\hline $\mathbf{1 0}$ & 38.5 & 3.6458 & 40.6267 & 3170 & 42.07 & 128.79 & 153.38 & 83.97 \\
\hline $\mathbf{1 1}$ & 45.5 & 3.5538 & 40.7068 & 3270 & 42.07 & 133.11 & 149.51 & 89.03 \\
\hline $\mathbf{1 2}$ & 57 & 3.9778 & 40.7542 & 3110 & 42.07 & 126.75 & 167.35 & 75.74 \\
\hline
\end{tabular}

Table 9. $\mathrm{NO}_{3}{ }^{-}$leachate results for depth discrete-subsample cut from Sample Tc2-9 cured in a humid environnement after which a 'freshly cut' surface was exposed to and leached in DI water.

\begin{tabular}{|c|c|c|c|c|c|c|c|c|}
\hline $\begin{array}{c}\text { Te } 2-9 \\
\text { waste form } \\
\text { sub- } \\
\text { sample } \\
\text { no. } \\
\end{array}$ & \begin{tabular}{|c|} 
Ave. \\
distance \\
from \\
top surface \\
$(\mathbf{m m})$ \\
\end{tabular} & $\begin{array}{c}\text { Sub- } \\
\text { sample } \\
\text { mass (g) }\end{array}$ & $\begin{array}{c}\text { Leachate } \\
\text { mass } \\
\text { (g or ml) }\end{array}$ & $\begin{array}{c}\mathrm{NO}_{3} \\
\text { leached } \\
\text { from } \\
\text { Tc } 2-9 \\
\text { (mg/L) }\end{array}$ & $\begin{array}{l}\mathrm{NO}_{3}^{-} \\
\text {in } 1 \mathrm{~g} \\
\text { waste } \\
\text { form } \\
\text { (mg) }\end{array}$ & $\begin{array}{c}\mathrm{NO}_{3}^{-} \\
\text {Leached } \\
\text { (mg) }\end{array}$ & $\begin{array}{c}\mathrm{NO}_{3}{ }^{-} \text {in } \\
\text { sample } \\
\text { before } \\
\text { leached } \\
(\mathrm{mg})\end{array}$ & $\begin{array}{c}\% \mathrm{NO}_{3}^{-} \\
\text {Leached }\end{array}$ \\
\hline 1 & \begin{tabular}{ll|}
0.8 \\
\end{tabular} & 2.14 & 41.6762 & 583 & 36.3 & 24.30 & 77.66 & 31.29 \\
\hline 2 & 3 & 2.9398 & 41.881 & 1567 & 36.3 & 65.63 & 106.69 & 61.52 \\
\hline 3 & 6.3 & 3.2305 & 40.7152 & 2597 & 36.3 & 105.74 & 117.23 & 90.19 \\
\hline 4 & 9.5 & 4.5142 & 39.9093 & 2243 & 36.3 & 89.52 & 163.82 & 54.64 \\
\hline 5 & 13 & 2.6674 & 41.0332 & 2420 & 36.3 & 99.30 & 96.80 & 102.58 \\
\hline 6 & 17 & 3.2903 & 40.5942 & 3005 & 36.3 & 121.99 & 119.40 & 102.16 \\
\hline 7 & 22.5 & 3.5838 & 40.7836 & 3165 & 36.3 & 129.08 & 130.06 & 99.25 \\
\hline 8 & 28 & 2.9481 & 41.5034 & 2668 & 36.3 & 110.73 & 106.99 & 103.50 \\
\hline 9 & 32.5 & 2.5505 & 39.7714 & 2239 & 36.3 & 89.05 & 92.56 & 96.21 \\
\hline 10 & 38.5 & 3.6458 & 40.6267 & 3014 & 36.3 & 122.45 & 132.31 & 92.55 \\
\hline 11 & 45.5 & 3.5538 & 40.7068 & 3048 & 36.3 & 124.07 & 128.97 & 96.21 \\
\hline 12 & 57 & 3.9778 & 40.7542 & 3042 & 36.3 & 123.97 & 144.35 & 85.88 \\
\hline
\end{tabular}


Table 10. Na leachate results for depth-discrete subsample cut from Sample Te2-10 cured in a humid environnement after which a 'freshly cut' surface was exposed to and leached in unsaturated Hanford sediment with 5 wt.\% moisture.

\begin{tabular}{|c|c|c|c|c|c|c|c|c|}
\hline $\begin{array}{c}\text { Tc 2-10 } \\
\text { wasteform } \\
\text { sub- } \\
\text { sample } \\
\text { no. }\end{array}$ & $\begin{array}{c}\text { Ave. } \\
\text { distance } \\
\text { from } \\
\text { top surface } \\
\text { (mm) }\end{array}$ & $\begin{array}{c}\text { Sub- } \\
\text { sample } \\
\text { mass (g) }\end{array}$ & $\begin{array}{c}\text { Leachate } \\
\text { mass } \\
\text { (g or } \mathbf{m l})\end{array}$ & $\begin{array}{c}\text { leached } \\
\text { from } \\
\text { Tc 2-10 } \\
\text { (mg/L) }\end{array}$ & $\begin{array}{c}\text { Na in } \\
\mathbf{1 g} \\
\text { waste } \\
\text { form } \\
\text { (mg) }\end{array}$ & $\begin{array}{c}\text { Na } \\
\text { leached } \\
\text { (mg) }\end{array}$ & $\begin{array}{c}\text { Na in } \\
\text { sample } \\
\text { before } \\
\text { leached } \\
\text { (mg) }\end{array}$ & $\begin{array}{c}\text { \% Na } \\
\text { leached }\end{array}$ \\
\hline $\mathbf{1}$ & $\mathbf{0 . 8}$ & 2.1023 & 41.2665 & 515 & 42.07 & 21.25 & $\mathbf{8 8 . 4 4}$ & 24.03 \\
\hline $\mathbf{2}$ & 2.8 & 2.6947 & 41.066 & 1450 & 42.07 & 59.55 & 113.37 & 52.53 \\
\hline $\mathbf{3}$ & 5.5 & 3.5261 & 40.8766 & 2820 & 42.07 & 115.27 & 148.34 & 77.71 \\
\hline $\mathbf{4}$ & $\mathbf{8 . 3}$ & 3.2316 & 40.7629 & 2750 & 42.07 & 112.10 & 135.95 & 82.45 \\
\hline $\mathbf{5}$ & 10.8 & 3.1107 & 41.0904 & 2930 & 42.07 & 120.39 & 130.87 & 92.00 \\
\hline $\mathbf{6}$ & 13.8 & 4.8403 & 39.87 & 4380 & 42.07 & 174.63 & 203.63 & 85.76 \\
\hline $\mathbf{7}$ & 17.8 & 6.424 & 39.2801 & 5720 & 42.07 & 224.68 & 270.26 & 83.14 \\
\hline $\mathbf{8}$ & 23.5 & 9.9767 & 37.3432 & 8070 & 42.07 & 301.36 & 419.72 & 71.80 \\
\hline $\mathbf{9}$ & 30.0 & $\mathbf{6 . 2 2 4 3}$ & 39.6078 & 5540 & 42.07 & 219.43 & 261.86 & 83.80 \\
\hline $\mathbf{1 0}$ & 37.5 & 7.4323 & 38.5899 & 6270 & 42.07 & 241.96 & 312.68 & 77.38 \\
\hline $\mathbf{1 1}$ & 47.0 & 5.7655 & 39.8804 & 4880 & 42.07 & 194.62 & 242.55 & $\mathbf{8 0 . 2 4}$ \\
\hline $\mathbf{1 2}$ & 60.0 & 7.632 & 38.6221 & 5840 & 42.07 & 225.55 & 321.08 & 70.25 \\
\hline
\end{tabular}

Table 11. $\mathrm{NO}_{3}^{-}$leachate results for depth-discrete subsample cut from Sample Tc2-10 cured in a humid environnement after which a 'freshly cut' surface was exposed to and leached in unsaturated Hanford sediment with 5 wt.\% moisture.

\begin{tabular}{|c|c|c|c|c|c|c|c|c|}
\hline \begin{tabular}{|c|} 
Te $2-10$ \\
wasteform \\
sub- \\
sample \\
no. \\
\end{tabular} & \begin{tabular}{|c|} 
Ave. \\
distance \\
from \\
top surface \\
(mm) \\
\end{tabular} & $\begin{array}{c}\text { Sub- } \\
\text { sample } \\
\text { mass (g) }\end{array}$ & $\begin{array}{c}\text { Leachate } \\
\text { mass } \\
\text { (g or ml) }\end{array}$ & $\begin{array}{c}\mathrm{NO}_{3}^{-} \\
\text {Leached } \\
\text { from } \\
\text { Tc 2-10 } \\
(\mathrm{mg} / \mathrm{L}) \\
\end{array}$ & $\begin{array}{l}\mathrm{NO}_{3}^{-} \\
\text {in } 1 \mathrm{~g} \\
\text { waste } \\
\text { form } \\
\text { (mg) }\end{array}$ & $\begin{array}{c}\mathrm{NO}_{3}^{-} \\
\text {Leached } \\
\text { (mg) }\end{array}$ & $\begin{array}{l}\mathrm{NO}_{3}^{-} \text {in } \\
\text { sample } \\
\text { before } \\
\text { leached } \\
\text { (mg) }\end{array}$ & $\begin{array}{c}\% \\
\mathrm{NO}_{3}^{-} \\
\text {Leached }\end{array}$ \\
\hline 1 & \begin{tabular}{|l|}
0.8 \\
\end{tabular} & 2.1023 & 41.2665 & 153 & 36.3 & 6.31 & 76.29 & 8.28 \\
\hline 2 & 2.8 & 2.6947 & 41.066 & 1120 & 36.3 & 45.99 & 97.79 & 47.03 \\
\hline 3 & 5.5 & 3.5261 & 40.8766 & 2780 & 36.3 & 113.64 & 127.96 & 88.81 \\
\hline 4 & 8.3 & 3.2316 & 40.7629 & 2710 & 36.3 & 110.47 & 117.27 & 94.20 \\
\hline 5 & 10.8 & 3.1107 & 41.0904 & 2950 & 36.3 & 121.22 & 112.89 & 107.38 \\
\hline 6 & 13.8 & 4.8403 & 39.87 & 4360 & 36.3 & 173.83 & 175.65 & 98.96 \\
\hline 7 & 17.8 & 6.424 & 39.2801 & 6060 & 36.3 & 238.04 & 233.13 & 102.11 \\
\hline 8 & 23.5 & 9.9767 & 37.3432 & 9320 & 36.3 & 348.04 & 362.05 & 96.13 \\
\hline 9 & 30.0 & 6.2243 & 39.6078 & 5740 & 36.3 & 227.35 & 225.88 & 100.65 \\
\hline 10 & 37.5 & 7.4323 & 38.5899 & 6900 & 36.3 & 266.27 & 269.72 & 98.72 \\
\hline 11 & 47.0 & 5.7655 & 39.8804 & 5170 & 36.3 & 206.18 & 209.23 & 98.54 \\
\hline 12 & 60.0 & 7.632 & 38.6221 & 6530 & 36.3 & 252.20 & 276.97 & 91.06 \\
\hline
\end{tabular}




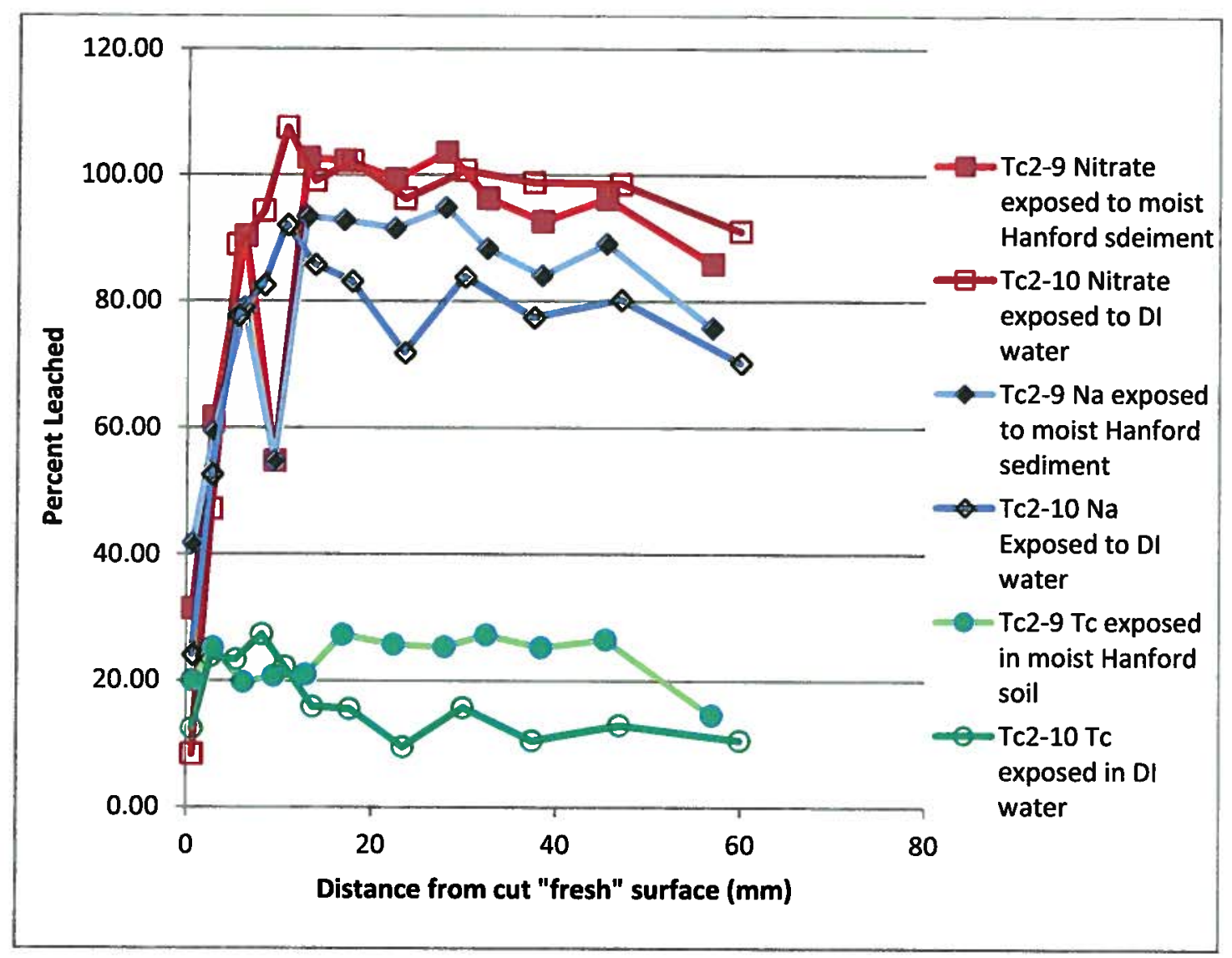

Figure 5. $\mathrm{Na}, \mathrm{NO}_{3}{ }^{-}$, and $\mathrm{Tc}-99$ percents leached from depth-discrete subsamples as a function of distance from fresh surfaces exposed to unsaturated Hanford sediment and DI water.

Table 12. Summary of $\mathrm{NO}_{3}^{-}, \mathrm{Na}$, and $\mathrm{Tc}$ leached as a function of distance from top surface of TC2-9 (exposed to Hanford sediment) and Tc2-10 (exposed to DI water).

\begin{tabular}{|c|c|c|c|c|c|c|c|}
\hline \multicolumn{4}{|c|}{ Tc2-9 Exposd to Hanford sediment } & \multicolumn{4}{|c|}{ Tc2-10 Exposed to DI water } \\
\hline \multirow{2}{*}{$\begin{array}{c}\text { Distance from } \\
\text { exposed surface } \\
(\mathbf{m m})\end{array}$} & $\mathbf{N O}_{3}^{-}$ & $\mathbf{N a}$ & Te & \multirow{2}{*}{$\begin{array}{l}\text { Distance from } \\
\text { exposed surface } \\
(\mathrm{mm})\end{array}$} & $\mathrm{NO}_{3}{ }^{-}$ & $\mathbf{N a}$ & Tc \\
\hline & \multicolumn{3}{|c|}{ \% Leached } & & \multicolumn{3}{|c|}{$\%$ Leached } \\
\hline 0 to 0.8 & 31 & 42 & 20 & 0 to 0.8 & 8 & 24 & 12 \\
\hline 0.8 to 9.5 & 69 & 64 & \multirow{2}{*}{24} & 0.8 to 3 & 47 & 53 & 24 \\
\hline 9.5 to $46^{*}$ & 99 & 91 & & 3 to 60 & 97 & 80 & -- \\
\hline 46 to 57 & 86 & 76 & 13 & 3 to $11^{*}$ & -- & -- & 24 \\
\hline-- & -- & -- & - & 11 to 60 & -- & -- & 13 \\
\hline
\end{tabular}

* Approximante depth of oxygen ingress during exposure.

Red shading in Table 12 indicates the subsample depths relative to fresh cut surfaces from which soluble ions were removed as the result of migration into the leaching media. Consequently, less than $100 \%$ of the original soluble ion concentrations were present in the samples at the time depth-discrete subsamples were prepared and leached. See Equation 2.

Equation 2. Mass extracted from depth-discrete subsample

(Initial concentration - Mass transferred to soil / water) 


\section{CONCLUSIONS}

Based on the results presented in this report, leaching crushed depth-discrete subsamples appears to be a suitable method for evaluating the effects of exposure to moist air and other environmental conditions expected in disposal environments on solubiliby / leachability of redox sensitive contaminants in cementitious waste forms. The method is useful in identifying the contaminant specific oxidation fronts in cured chemically reducing cementitious waste forms and provides the mass fraction of soluble redox sensitive contaminants and other soluble contaminants as a function of distance from a surface exposed to moist air. The soluble fraction is of a chemical species is that portion available to diffusion through the waste form pore solution. The effective diffusion coefficients for the soluble fractions of redox sensitive contaminants will be approximately the same as that for nitrate.

Coating all sides of a cylindrical sample with an impermeable epoxy and cutting a fresh surface 2 to 2.5 $\mathrm{cm}$ from the original top surface eliminates potential sample inhomogeneity as the result of settling as a reason from observed results and provides 1-D soluble ion transport and gas transport information.

Based on nitrate (assumed to $100 \%$ soluble during curing and exposure) leaching results for the depthdiscrete subsamples depletion regions were identified which extended 9.5 and $3 \mathrm{~mm}$ into samples Tc2-9 (exposed to Hanford sediment) and Tc2-10 (DI water). Lower mass fractions of nitrate were leached the depth-discrete samples taken from these near surface locations presumably because a significant portion of the nitrate had already migrated into the soil or water. Subsample leaching results can be interpreted in the same way for the same regions in the two samples tested.

Soluble Tc was leached from all of the depth-discrete subsamples from both Tc2-9 and Tc2-10 which strongly suggests that oxygen was present in the entire length of both samples. About 24 mass percent of the Tc in the original sample, was leached (soluble) from subsamples between 0.8 and $46 \mathrm{~mm}$ below the exposed surface of Tc2-9 (exposed to Hanford sediment). The same percent (24\%) was leached from the subsamples between 0.8 and $11 \mathrm{~mm}$ below the exposed surface of Tc2-10 (exposed to DI water). This suggests that the rate of oxygen migration into the sample exposed to soil was faster than the rate of migration into the sample exposed to water which is consistent with the more rapid transport of ions through a gas phase as compared to a liquid phase. It is assumed that moisture in the Handord sediment was not sufficient to completely block the surface pores with respect to gas transport across the soil-waste form boundary.

Additional data are required to fully understand and quantify the progression of the region depleted in soluble ions and the rate of oxygen ingress and oxidation of redox sensitive contaminants such as Tc. However, these scoping studies provide insights of the multiple mechanisms affecting the solubility and leachability of redox sensitive contaminats.

In conclusion, leaching monolithic porous cementititous waste forms in water appears to be nonconservative for determining the concentration of soluble redox sensitive contaminants such as $\mathrm{TcO}_{4}{ }^{-}$and $\mathrm{CrO}_{4}{ }^{2-}$ in a waste form. Under saturated conditions (leaching in water) the water blocks the pores and inhibits oxygen transport due to the low solubility of oxygen in water. However, under drying conditions or partially saturated conditions, oxygen can diffuse through the gas phase at a rate several orders of magnitude higher than diffusion through water. Once oxidized the redox sensitive contaminants are soluble and available to be leached via diffusion and / or advection.

Leaching monolithic samples in water provides effective diffusion coefficients which takes into account porosity, tortuosity, i.e., physical entrapment, of soluble species. Leaching crushed samples provides a means of estimating the concentrations of soluble contaminants in a waste form. 


\section{REFERENCES}

1. Shuh, D. K., N. Kaltsoyannis, J. J. Bucher, N. M. Edelstein, S. B. Clark, H. Nitsche, W. Lukens, W. S. Yang, and J. C. Bryan, 1994. "Environmental Applications of XANES: Speciation of Tc in Cement after Chemical Treatment with Se after Bacterial Uptake," Mat. Res. Soc. Symp. Proc. \#44, P. 323-3328.

2. Shuh, D. K., N. M. Edelstein, C. J. Burns, W. W. Lukens, 2003. Research Program to Investigate the Fundamental Chemistry of Technetium, EMSP-73778, Lawrence Berkeley National Laboratory, Berkeley, CA.

3. Lukens, W. W., J. J. Bucher, D. K. Shuh, and N. M. Edelstein, 2005. "Evolution of Technetium Speciation in Reducing Grout," Environ. Sci. Technol. 30:8064-8070.

4. Almond, P. M. and C. A. Langton, 2013. "Task Technical and Quality Assurance Plan for Characterization of the Technetium Oxidation Front for Cast Stone," SRNL-RP-2013-00112, Savannah River National Laboratory, Aiken, SC 29808.

5. Almond, P. M., D. I. Kaplan, C. A. Langton, D. B. Stefanko, W. A. Spencer, A. Hatfield, and Y. Arai. 2012. "Method Evaluation and Field Sample Measurements for the Rate of Movement of the Oxidation Front in Saltstone," SRNL-STI-2012-00468, Revision 0, Savannah River National Laboratory, Savannah River Site, Aiken, SC, 29808.

6. Langton, C. A., D. B. Stefanko, and H. H. Burns, 2012. "Saltstone Oxidation Study: Leaching Method," SRNL-STI-2012-00728, Savannah River National Laboratory, Savannah River Site, Aiken, SC, 29801 and WM Symp., Feb. 24 to 28, 2013, Phoenix AZ.

7. Langton, C. A. Langton, D. S. Kosson, A. C. Garrabrants, K. G. Brown, 2009. "Reference Cases for Use in the Cementitious Barriers Partnership Project" WM Symp., March 1-5, 2009, Phoenix AZ.

8. US DOE Inter-Entity Work Order, EWO No. MOSRV00091, 2013. "Low Temperature Waste Forms Coupled with Tc Removal / Waste Feed Acceptance and Product Qualification.

9. Certa, P. J., P.A. Empey, and N. M. Wells, 2011. "River Protection Project System Plan," ORP11242, Revision 6, Washington River Protection Solutions, LLC, Richland Washington.

10. Russell, R. L., A. D. Cozzi, et. al., 2013. "Letter Report: LAW Simulant Development for Cast Stone Screening Tests," PNNL-22352, Pacific Northwest National Laboratory, Richland, WA.

11. Wellman, D., 2013. Personal communication between D. Wellman, Pacific Northwest national Laboratory, WA and C. A. Langton, Savannah River National Laboratory, SC.

12. U.S. EPA, (2007). “Toxicity Characteristic Leaching Procedure, Method 1311," U.S. Environmental Protection Agency, SW 846, Rev. 6, Feb. 2007, Washington DC.

13. ASTM D 2216 2010. "Standard Test Methods for Laboratory Determination of Water (Moisture) Content of Soil and Rock by Mass," American Society of Testing and Materials, Philadelphia, PA. 
ATTACHMENT 1. CHARACTERIZATION OF AS-RECEIVED HANFORD SOL MOISTURE CONTENT AND SATURATED MOISTURE CONTENT [13] 
URS

Savannah River Site

Allachment BI

ASR 18-175 (04/13)

Moisture-Density Relationship Test

(Typical Form)

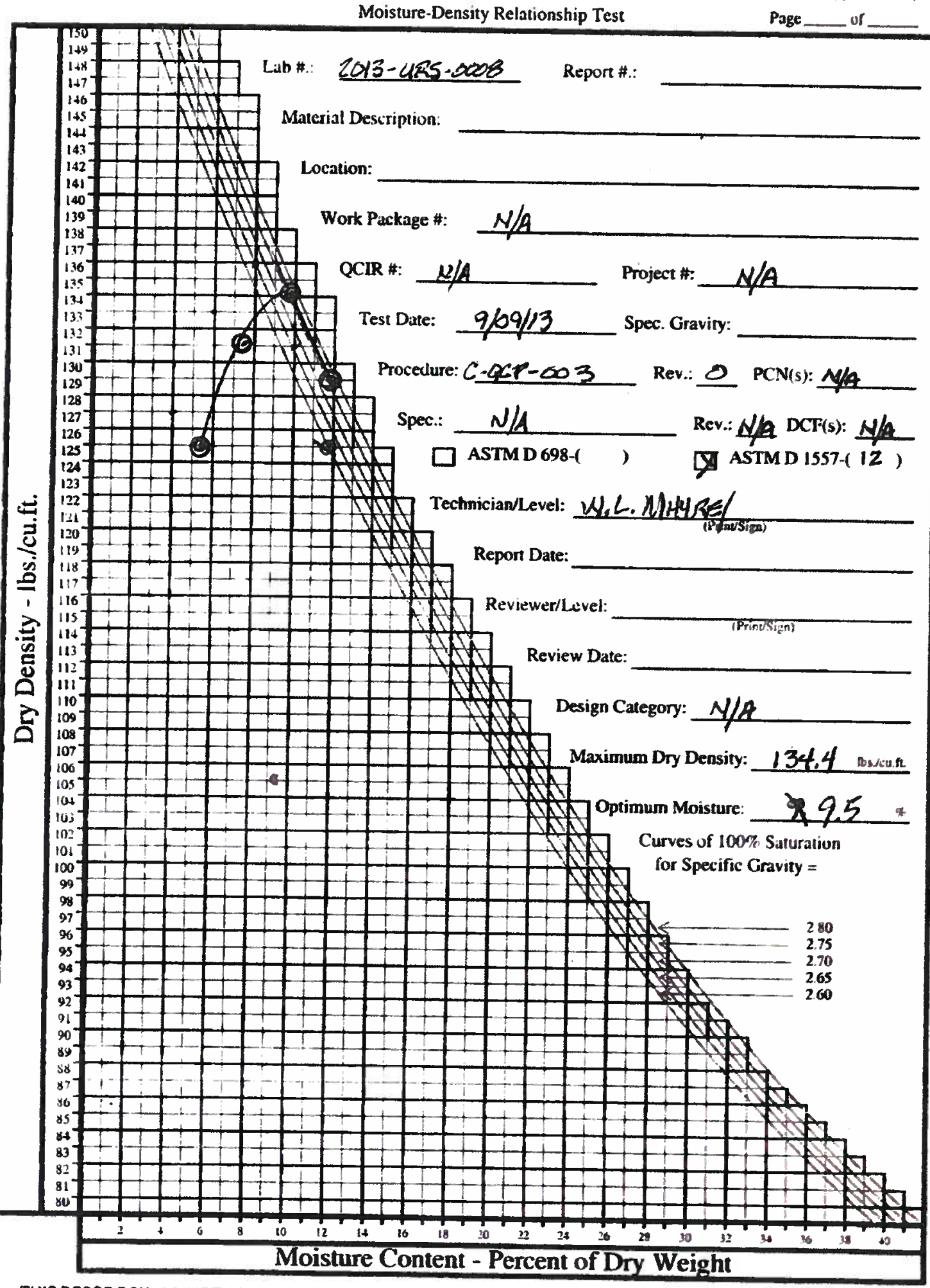

THIS REPOR I SHALL NOT BE REPORDUCED. EXCEPT IN FULL. IVITHOUT THE WRITTEN APPROVAL OF THE LABORATORY 


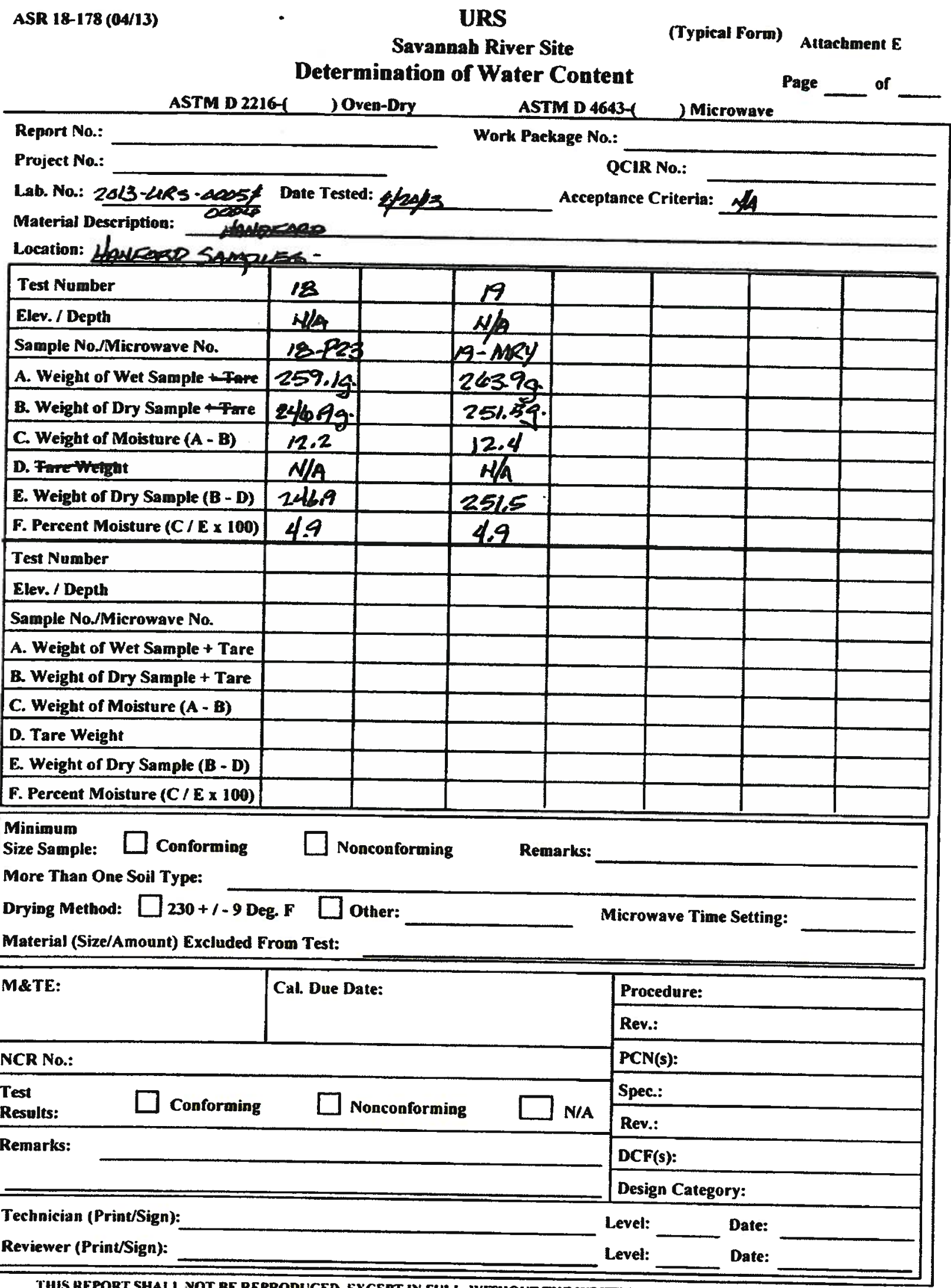

THIS REPORT SHALL, VOT BE REPRODUCED. EXCEPT IN FULL, IVTHOUT THE WRITIEN APPROVAL OF THE LABORATORY. 
ATTACHMENT 2. ANALYTICAL RESULTS FOR SUBSAMPLE LEACHATES 


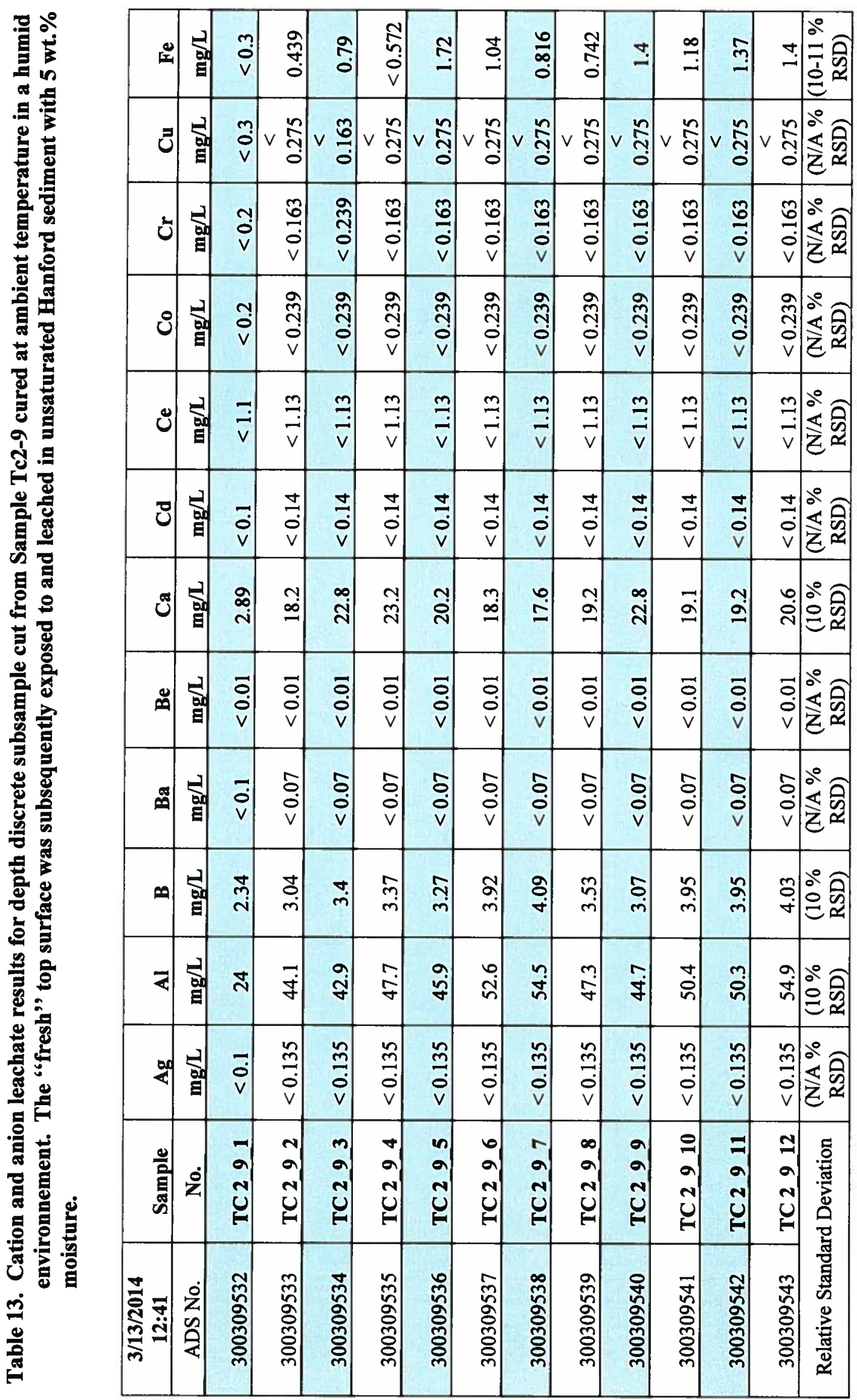




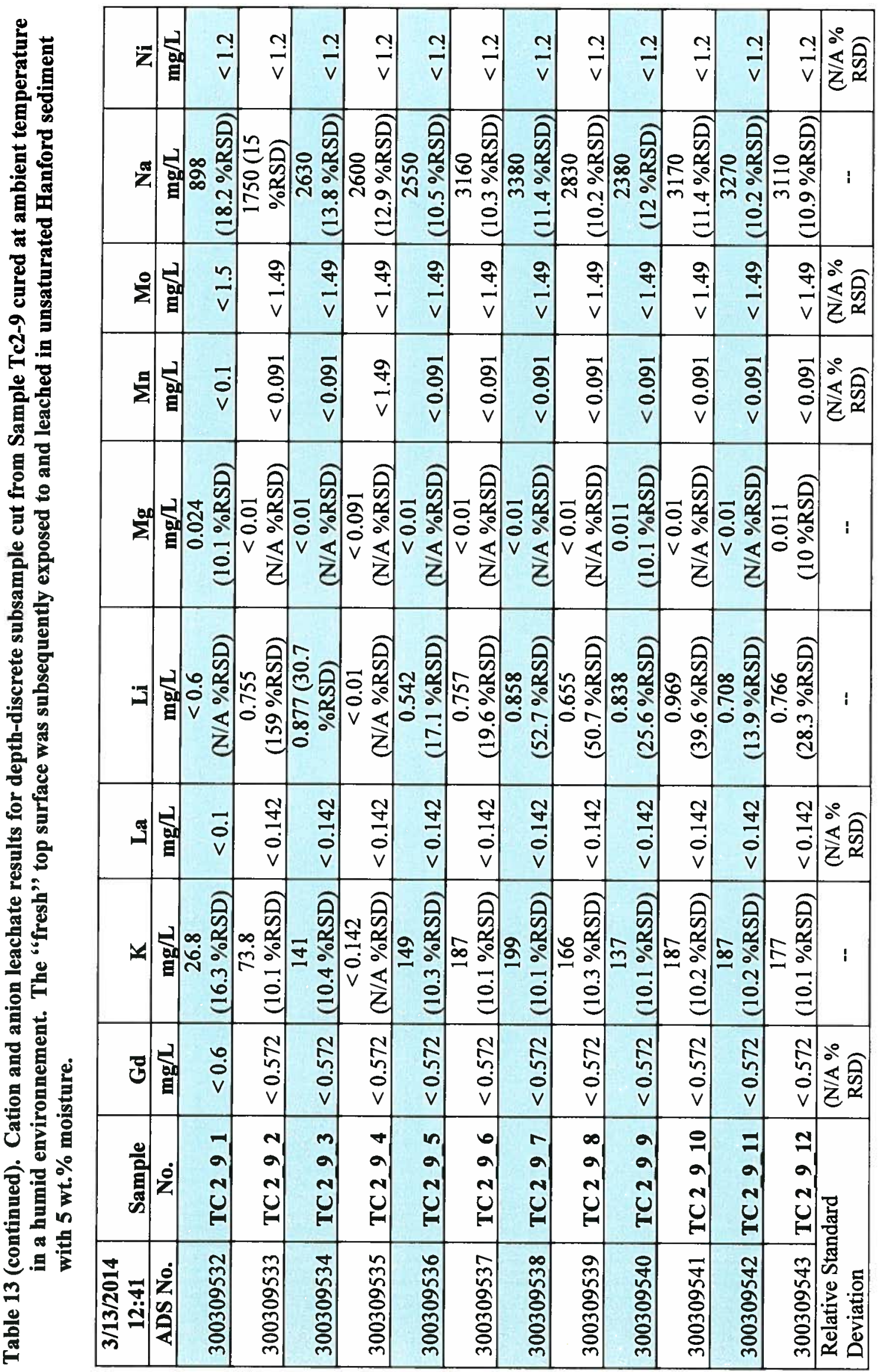




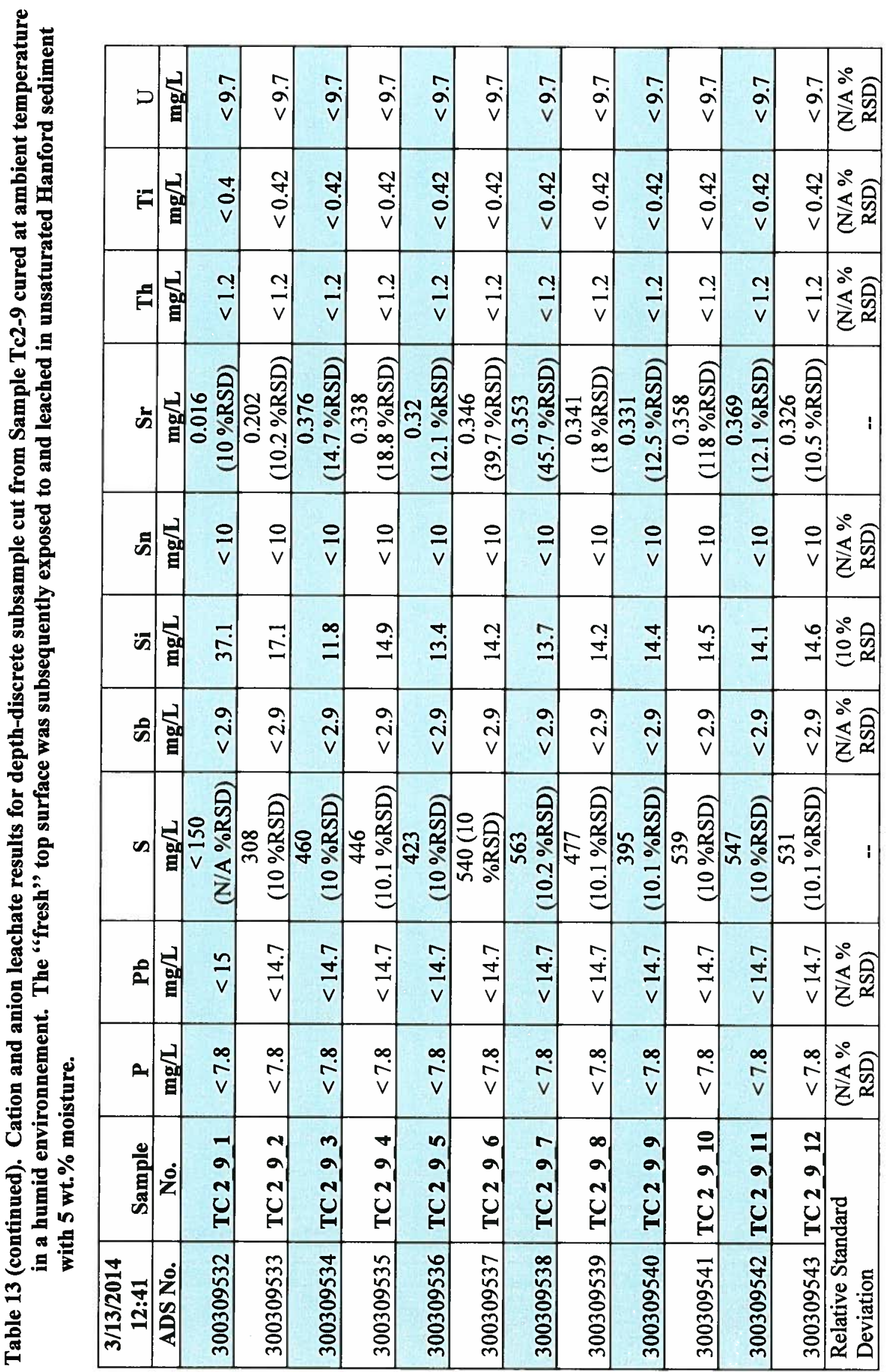




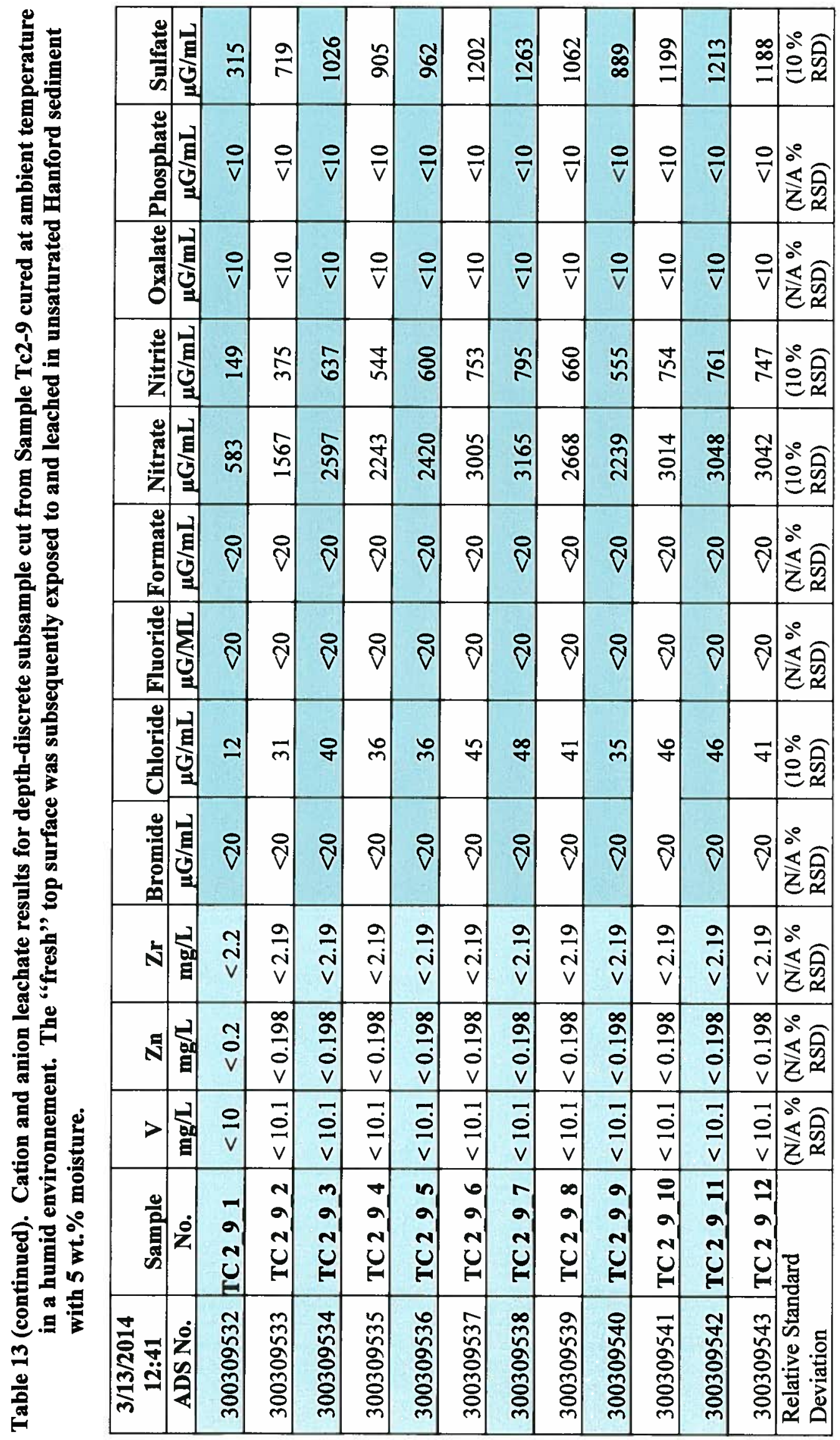




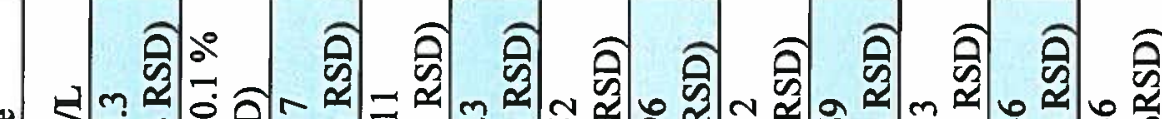

a d0

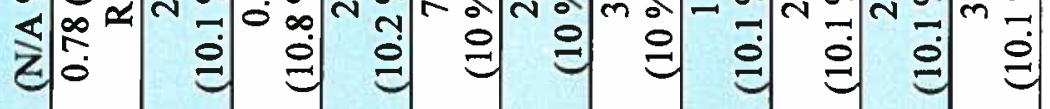

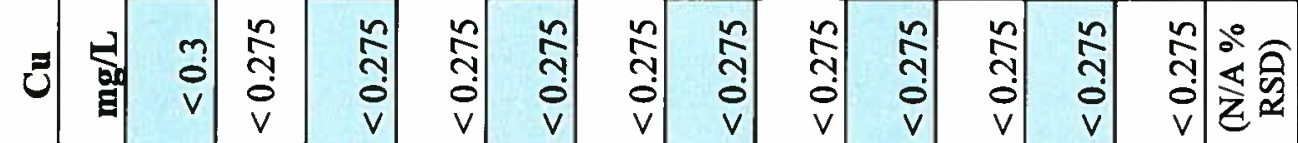

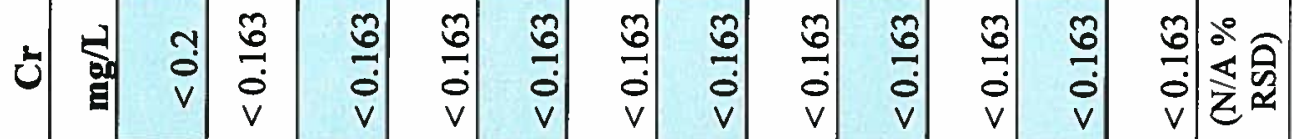

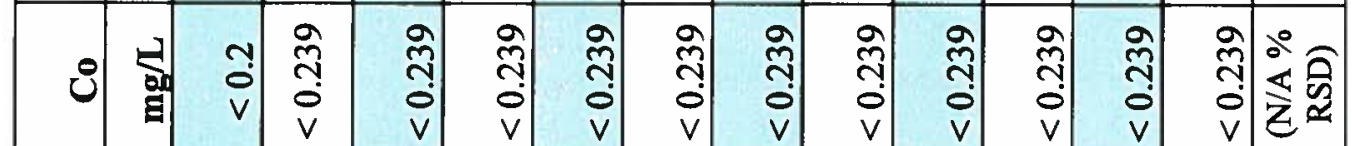

பํ.

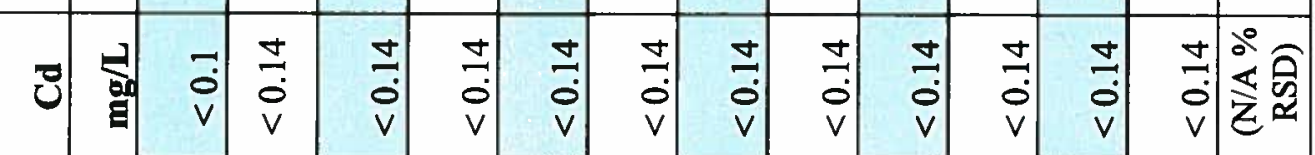

\section{을}

它

Uึ

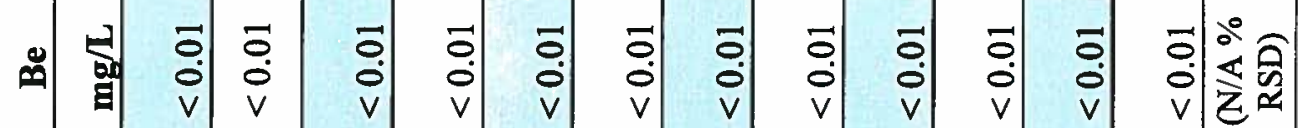

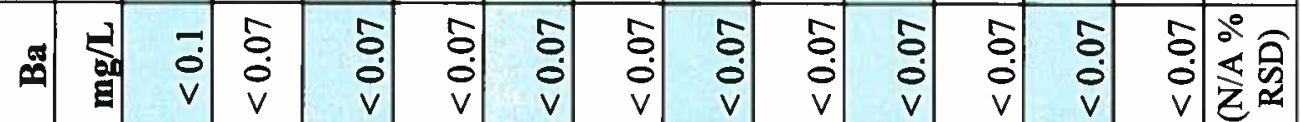

\section{s}

๓ 뱁 흘

《) 뱁

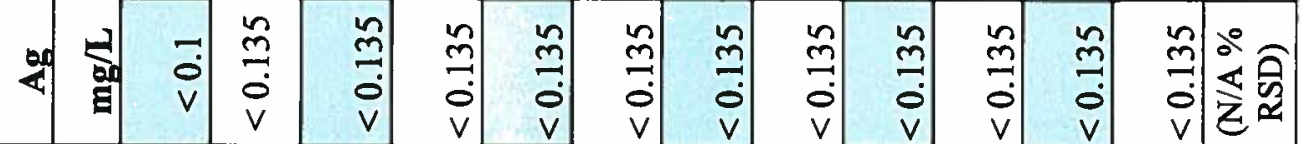

藏

m

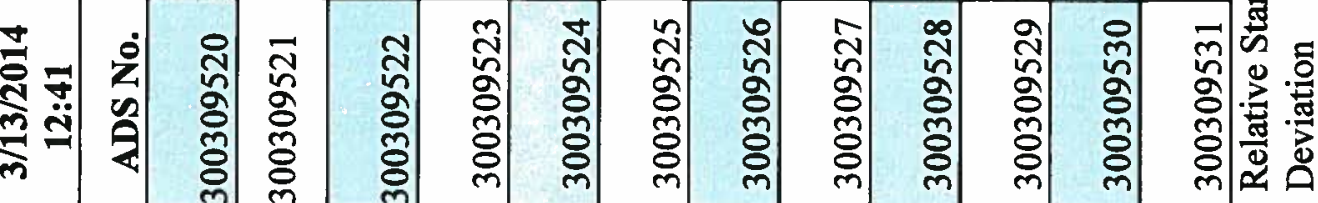




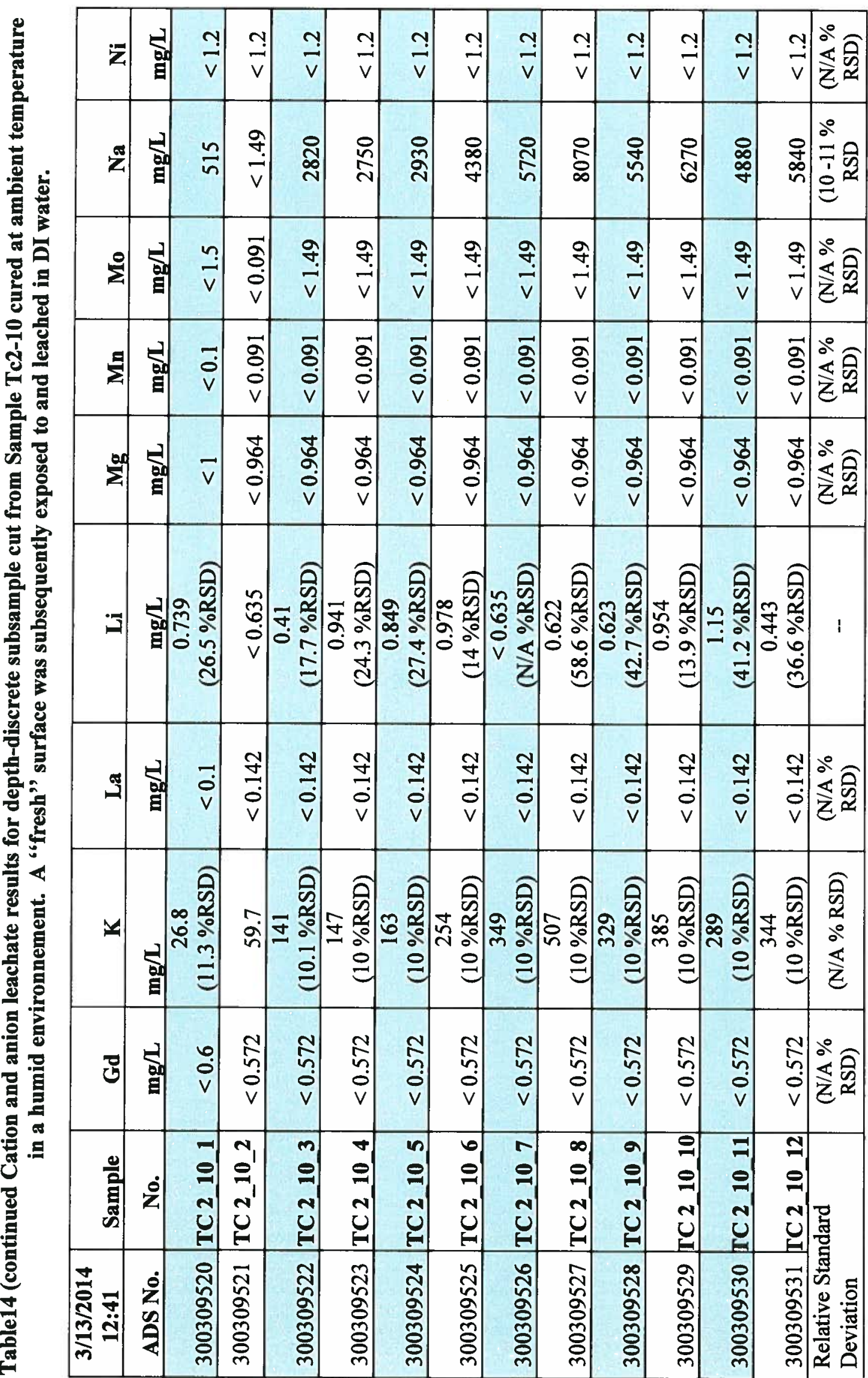




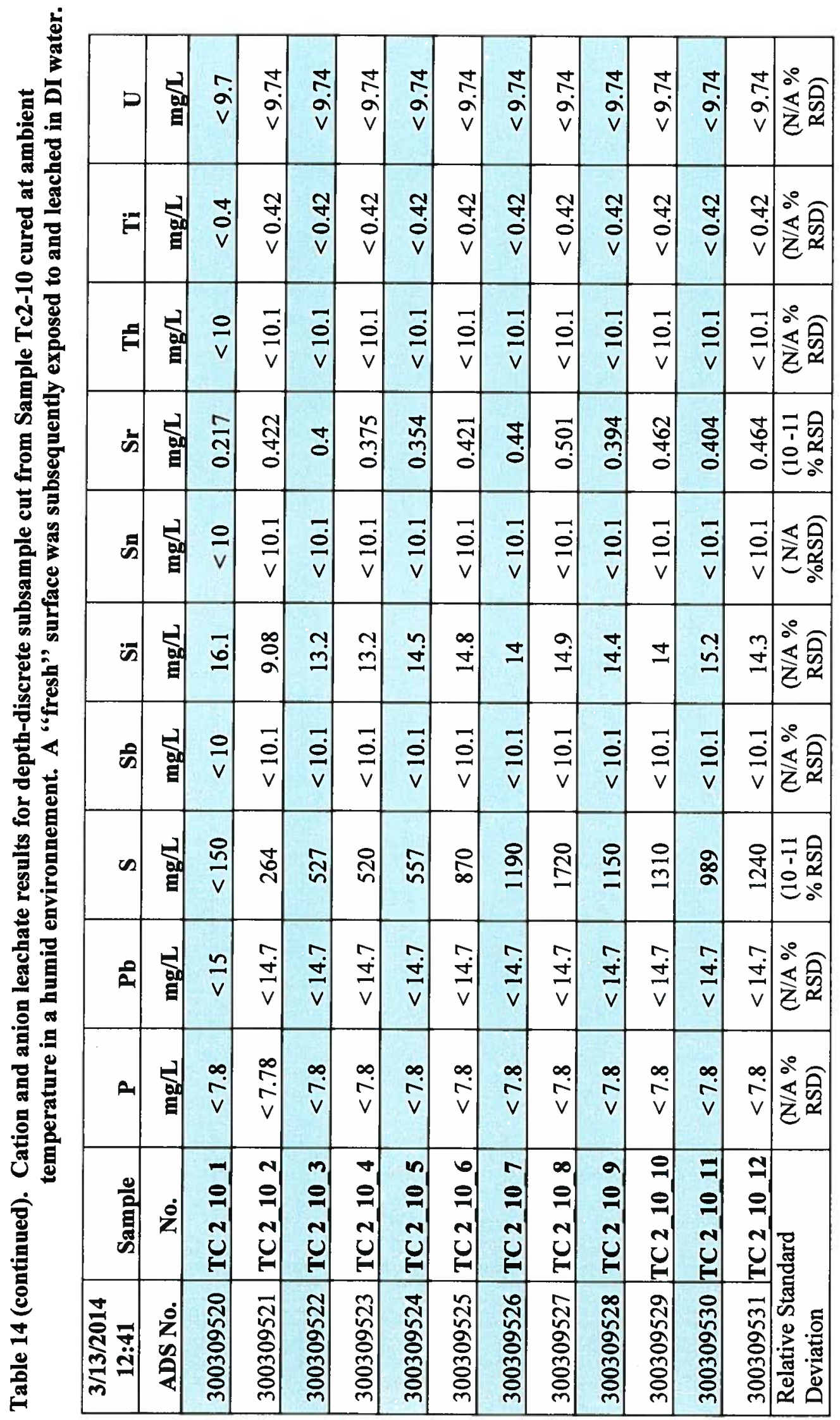




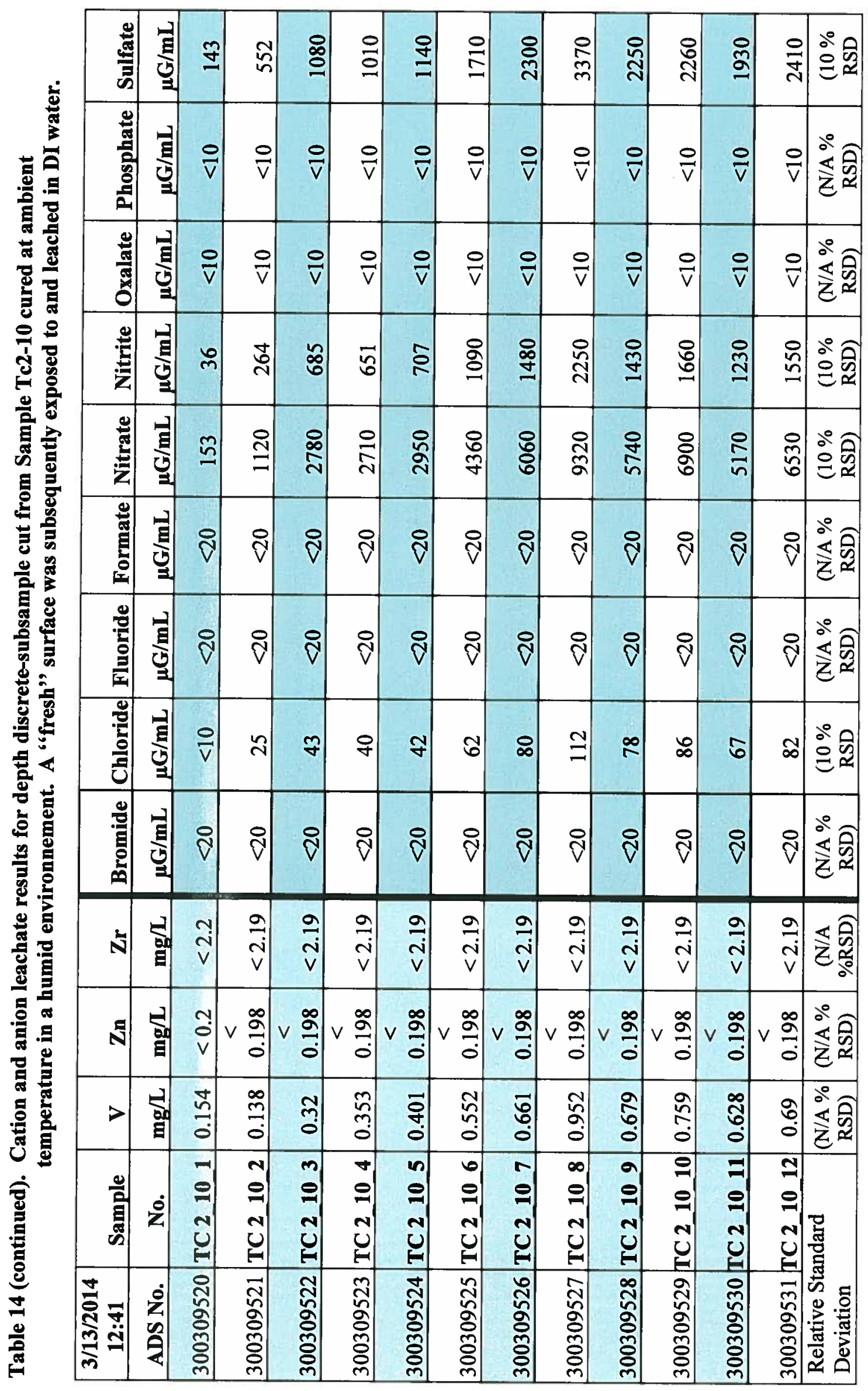




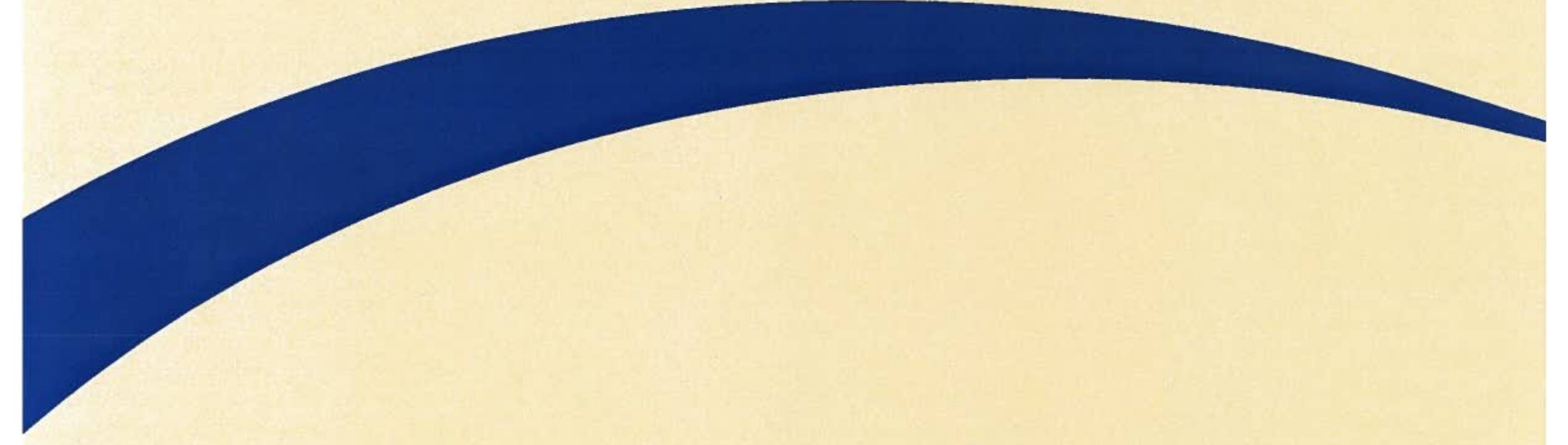

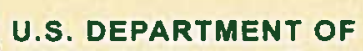
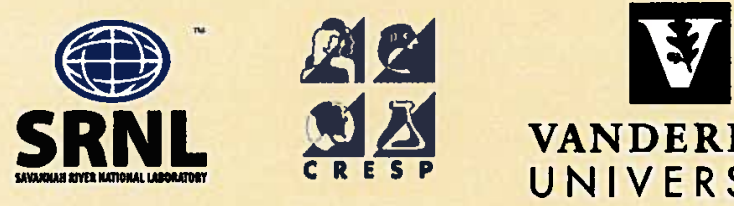

VANDERBILT

UNIVERSITY

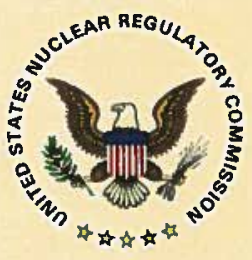

NGT

National Institute of

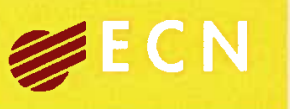




\section{DISTRIBUTION}

C. E. Bagwell, 999-W

C. F. Brown, PNNL

T. B. Brown, 773-A

H. H. Burns, 773-41A

P. A. Cavanah, WRPS

A. D. Cozzi, 999-W

D. A. Crowley, 773-43A

J. A. Diediker, DOE-ORP

S. D. Fink, 773-A

G. P. Flach, 773-42A

K. M. Fox, 999-W

J. C. Griffin, 773-A

B. J. Gutierrez, DOE-SR, 704-S

E. K. Hansen, 999-W

C. C. Harrington, DOE-ORP

C. C. Herman, 773-A

E. N. Hoffman, 999-W

V. Jain. 766-H

J. T. Knight, 704-S

C. A. Langton, 773-43A

S. L. Marra, 773-A

F. M. Pennebaker, 773-42A

R. D. Peterson, PNNL

S. H. Pfaff, DOE-ORP

E. M. Pierce, ORNL

W. G. Ramsey, WRPS

K. H. Rosenberger, 705-1C

K. A. Roberts, 773-43A

R. J. Serne, PNNL

S. P. Simner, 249-8H

P. C. Suggs, 704-S

K. H. Subramanian, WRPS

D. J. Swanberg, WRPS

S. A. Thomas, 705-1C

J. H. Westsik, PNNL

W. R. Wilmarth, 773-A 